University of Nebraska - Lincoln

DigitalCommons@University of Nebraska - Lincoln

Papers in the Earth and Atmospheric Sciences

Earth and Atmospheric Sciences, Department

$2-24-2012$

\title{
Evolution of the Earliest Horses Driven by Climate Change in the Paleocene-Eocene Thermal Maximum
}

\author{
Ross Secord \\ University of Nebraska-Lincoln, rsecord2@unl.edu \\ Jonathan I. Bloch \\ Florida Museum of Natural History, University of Florida, jbloch@flmnh.ufl.edu
}

Stephen G. B. Chester

Yale University, stephen.chester@yale.edu

Doug M. Boyer

Brooklyn College, City University of New York, douglasmb@gmail.com

Aaron R. Wood

South Dakota School of Mines and Technology, Aaron.Wood@sdsmt.edu

See next page for additional authors

Follow this and additional works at: https://digitalcommons.unl.edu/geosciencefacpub

Part of the Earth Sciences Commons

Secord, Ross; Bloch, Jonathan I.; Chester, Stephen G. B.; Boyer, Doug M.; Wood, Aaron R.; Wing, Scott L.; Kraus, Mary J.; Mclnerney, Francesca A.; and John Krigbaum, "Evolution of the Earliest Horses Driven by Climate Change in the Paleocene-Eocene Thermal Maximum" (2012). Papers in the Earth and Atmospheric Sciences. 310.

https://digitalcommons.unl.edu/geosciencefacpub/310

This Article is brought to you for free and open access by the Earth and Atmospheric Sciences, Department of at DigitalCommons@University of Nebraska - Lincoln. It has been accepted for inclusion in Papers in the Earth and Atmospheric Sciences by an authorized administrator of DigitalCommons@University of Nebraska - Lincoln. 


\section{Authors}

Ross Secord, Jonathan I. Bloch, Stephen G. B. Chester, Doug M. Boyer, Aaron R. Wood, Scott L. Wing, Mary J. Kraus, Francesca A. McInerney, and John Krigbaum 


\title{
Evolution of the Earliest Horses Driven by Climate Change in the Paleocene-Eocene Thermal Maximum
}

\author{
Ross Secord, ${ }^{1,2}$ Jonathan I. Bloch, ${ }^{2}$, Stephen G. B. Chester, ${ }^{3}$ Doug M. Boyer, $^{4}$ \\ Aaron R. Wood, ${ }^{5,2}$ Scott L. Wing, ${ }^{6}$ Mary J. Kraus, ${ }^{7}$ Francesca A. McInerney, ${ }^{8}$ \\ John Krigbaum, ${ }^{9}$ \\ 1. Department of Earth and Atmospheric Sciences, University of Nebraska, Lincoln, NE 68588, USA \\ 2. Florida Museum of Natural History, University of Florida, Gainesville, FL 32611-7800, USA \\ 3. Department of Anthropology, Yale University, New Haven, CT, 06520, USA \\ 4. Department of Anthropology and Archaeology, Brooklyn College, City University of New York, New York, NY 11210, \\ USA \\ 5. Department of Geology and Geological Engineering, South Dakota School of Mines and Technology, Rapid City, SD \\ 57701, USA \\ 6. Department of Paleobiology, Smithsonian Museum of Natural History, Washington, DC 20560, USA \\ 7. Department of Geological Sciences, University of Colorado, Boulder, CO 80309, USA \\ 8. Department of Earth and Planetary Sciences, Northwestern University, Evanston, IL 60208, USA \\ 9. Department of Anthropology, University of Florida, Gainesville, FL 32611-7305, USA \\ Corresponding author - R. Secord, email: rsecord2@unl.edu
}

\begin{abstract}
Body size plays a critical role in mammalian ecology and physiology. Previous research has shown that many mammals became smaller during the Paleocene-Eocene Thermal Maximum (PETM), but the timing and magnitude of that change relative to climate change have been unclear. A high-resolution record of continental climate and equid body size change shows a directional size decrease of $\sim 30 \%$ over the first $\sim 130,000$ years of the PETM, followed by a $\sim 76 \%$ increase in the recovery phase of the PETM. These size changes are negatively correlated with temperature inferred from oxygen isotopes in mammal teeth and were probably driven by shifts in temperature and possibly high atmospheric $\mathrm{CO}_{2}$ concentrations. These findings could be important for understanding mammalian evolutionary responses to future global warming.
\end{abstract}

$I^{n}$

nterest in how organisms respond to climate change has intensified in recent years with projected warming of $\sim 2^{\circ}$ to $4^{\circ} \mathrm{C}$ over the next century (1). Although models can be developed to predict evolutionary responses to warming of this magnitude, empirical examples must be drawn from fossil or historical records. Here we report a dramatic example of shifts in body size in the earliest known horses (family Equidae) during the Paleocene-Eocene Thermal Maximum (PETM) ( 56 million years ago). The PETM is recognized in marine and continental records by an abrupt negative carbon isotope excursion (CIE) that lasted $\sim 175$ thousand years $(\mathrm{ky})$, caused by the release of thousands of gigatons of carbon to the ocean-atmosphere system (2, 3). Some marine records suggest that although $\delta^{13} \mathrm{C}$ values shifted rapidly at the onset of the CIE in $21 \mathrm{ky}$ or less (2), temperature increase was slower, peaking $60 \mathrm{ky}$ or more into the CIE (4) at $\sim 5^{\circ}$ to $10^{\circ} \mathrm{C}$ above pre-CIE levels $(5,6)$. We use oxygen isotope values in mammal teeth as a proxy for local temperature change in the continental interior of North America, and we show that equid body size during the PETM was negatively correlated with temperature.

In extant mammals and birds (endotherms), closely related species or populations within a species are generally smaller-bodied at lower latitudes, where ambient temperature is greater (7). This relationship, known as Bergmann's rule, is followed by $\sim 65$ to $75 \%$ of studied extant mammals $(8,9)$. The cause of Bergmann's rule is usually attributed to thermoregulation and the optimization of body size (10) and/ or the availability of food resources related to primary productivity (11). Bergmann's rule predicts that average mammalian body size should decrease with warming climate, and smaller size in endotherms has even been suggested as a third "universal" response to warming, along with changes in phenology and species distribution (10). Declining body size has been attributed to warming over decadal and millennial scales in some living endotherms $(12,13)$, but many counterexamples also exist (10). Furthermore, it is difficult to distinguish natural selection (genetic change) from ecophenotypic plasticity (morphological response not genetically fixed) over such short time scales. The size change documented here was, however, sustained over thousands of generations, strongly suggesting that natural selection was the cause. 
Previous studies lacked the stratigraphic resolution to recognize patterns in body size change within the PETM but demonstrated gross changes in size in several mammal lineages, based on first molar tooth area $(14,15)$. Size changes occurred in herbivorous ungulates (Perissodactyla, Artiodactyla, Condylarthra, and Tillodontia), Primates, and faunivores and omnivores (Creodonta, Carnivoramorpha, and Palaeanodonta), affecting both immigrant and endemic taxa (Figure 1). These changes conform well to Bergmann's rule in terms of the expected direction of size change. Quantifying published results, size reduction occurred in 10 Paleocene genera that ranged into the PETM, representing $38 \%$ of the range-through genera. This was followed by post-PETM size increases in eight of these genera, indicating that body size response was strongly taxon-specific (Figure 1 and table S7). Post-PETM size increases also occurred in an additional eight genera, seven of which first appeared in the PETM (Figure 1). Together these 16 genera represent a size increase in $40 \%$ of PETM genera that ranged into post-PETM biozone Wa-1 (Figure 2).

Sifrhippus [formerly Hyracotherium (16)] first appeared in North America and Europe during the PETM. Because of the lack of a plausible ancestor on these continents, it is widely thought to be an immigrant that crossed high-latitude dispersal routes opened by PETM warming (17). We use Sifrhippus to document mammalian body size change within the PETM. Sifrhippus is the most abundantly represented genus in new collections from the Cabin Fork area $\left(\sim 10 \mathrm{~km}^{2}\right)$ of the southern Bighorn Basin, Wyoming, and the only one for which detailed stratigraphic and quantitative morphological data are available. We also isotopically sampled Sifrhippus, Coryphodon (Pantodonta; large archaic herbivorous ungulates), and Ectocion and Copecion (phenacodontid condylarths; herbivorous ungulates of uncertain affinities). The PETM at Cabin Fork is represented by a 35-m-thick sequence of fluvial mudstones, floodplain soils (paleosols), and fluvial sandstones. We constructed an age model that assumes varying rates of sediment accumulation: Avulsion deposits (mudstones and thin sandstones) represent fast rates, and paleosols represent much slower rates [see the supporting material (SM)]. Local sections were correlated to a composite section (Figure 2) using marker beds traced with a differential Global Positioning System unit (SM).

The CIE at Cabin Fork is recorded in the carbonate component of mammalian tooth enamel $\left(\delta^{13} C_{E}\right)$ (Figure 2, A and B) and in bulk organics and leaf wax $n$-alkanes $(6,18) . \delta^{13} C_{E}$ in mammalian herbivores reflects the $\delta^{13} \mathrm{C}$ value of the vegetation they consume, with predictable

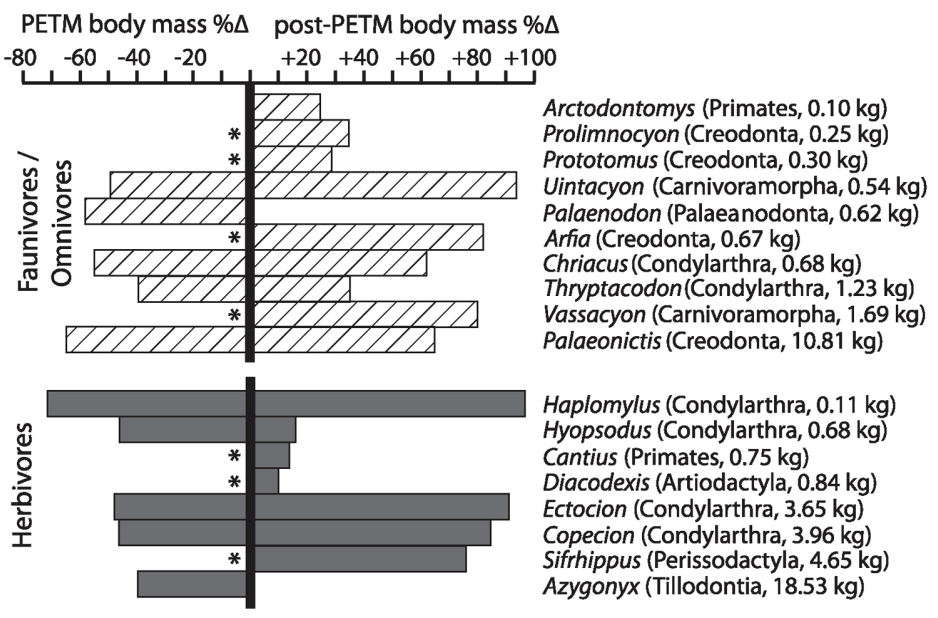

Figure 1. Summary of percent mean body size change in genera that exhibit change from the latest Paleocene to the PETM (left), and from the PETM to the post-PETM (right). No genus exhibits a size increase in the PETM or a decrease after the PETM. Compiled from published sources, except for Sifrhippus from this study. Asterisks indicate genera that first appear in the PETM. See table S7 for a summary of all PETM taxa and sources.

enrichment (19). Plants in turn track the $\delta^{13} \mathrm{C}$ value of atmospheric $\mathrm{CO}_{2}$, with influences from environmental factors such as humidity and vegetation density $(20,21)$. At Cabin Fork, phenacodontids (Ectocion and Copecion) record a negative shift of $\sim 4.6$ per mil (\%o) in $\delta^{13} C_{E}$ at the onset of the CIE (Figure 2A). This is consistent with estimates of atmospheric change of $\sim 4.6 \%$ during the PETM from a leaf discrimination model (20) and $\sim 4.0 \%$ from modeling of marine carbonate dissolution (2), indicating that phenacodontid $\delta^{13} C_{E}$ is primarily tracking atmospheric $\delta^{13} \mathrm{C}$ values, rather than environmental change.

Sifrhippus sandrae first appears at Cabin Fork near the base of the lowest intermittent red bed (LIRB) at $14.5 \mathrm{~m}$ (Figure 2). The onset of the CIE in most mammal teeth also begins at the base of the LIRB (Figure 2, A and B) but is recorded slightly lower $(13.75 \mathrm{~m})$ in dispersed bulk organics. The oldest specimens of $S$. sandrae had an average body size of $\sim 5.6 \mathrm{~kg}$, based on first lower molar area. Body size in S. sandrae progressively decreased from its first appearance at $14.5 \mathrm{~m}$ to the $41-\mathrm{m}$ level, with a total reduction of $\sim 30 \%$ over $\sim 130 \mathrm{ky}$ ( $P$ $<0.001$ ) (Figure 2D and SM). Individuals at $41 \mathrm{~m}$ had an average body weight of $\sim 3.9 \mathrm{~kg}$ and are among the smallest known horses. The dwarfing of S. sandrae was followed by a $\sim 76 \%$ increase in body size during the recovery phase of the CIE, to an average size of $\sim 7.0 \mathrm{~kg}$ (Figure 2D).

The mode of evolution (random, static, or directional) for Sifrhippus body size change was determined using a moving window log rate interval (mwLRI) analysis, which is a modification of the standard LRI analysis (22) (SM). Both methods assume that rates of change in a time series variable are inversely proportional to the interval of time over which rates are measured, because of the occurrence of small reversals in the variable. The relationship between rates of change and the lengths of intervals over which they are observed is used to determine evolutionary mode (22). Our mwLRI results indicate with 95\% confidence that Sifrhippus body size directionally decreased from its first appearance to the 41-m level, after which stratigraphic resolution and sample sizes are insufficient to distinguish between directional and random evolutionary change. Thus, Sifrhippus experienced sustained selection for diminutive body size for $\sim 130 \mathrm{ky}$.

To test whether body size change in Sifrhippus is significantly correlated with temperature, as predicted by Bergmann's rule, we used $\delta^{18} \mathrm{O}$ values in Coryphodon enamel $\left(\delta^{18} \mathrm{O}_{\mathrm{E}}\right)$ as a proxy for change in mean annual temperature (MAT). Coryphodon was a large water-dependent or semi-aquatic mammal $(21,23)$. Studies of ecologically similar living mammals have shown that their $\delta^{18} \mathrm{O}_{\mathrm{E}}$ faithfully records the $\delta^{18} \mathrm{O}$ of surface water (24, $25)$, which in turn is strongly correlated with air temperature at mid- to high latitudes (26). Sifrhippus first lower molar area is negatively correlated with Coryphodon $\delta^{18} \mathrm{O}_{\mathrm{E}}$ values $(P \leq 0.05, \mathrm{SM})$, suggesting that Sifrhippus body size decreased as ambient air temperature increased.

Greater aridity in the PETM could also have contributed to diminished body size by lowering primary productivity. Both floras and paleosols in the Bighorn Basin suggest increased aridity during at least parts of the PETM $(6,20,27)$. To test this, we used two aridity proxies. The first is based on the difference between mean $\delta^{18} \mathrm{O}_{\mathrm{E}}$ values in aridity-sensitive and aridity-insensitive mammals (24). Coryphodon should be aridity-insensitive because of 


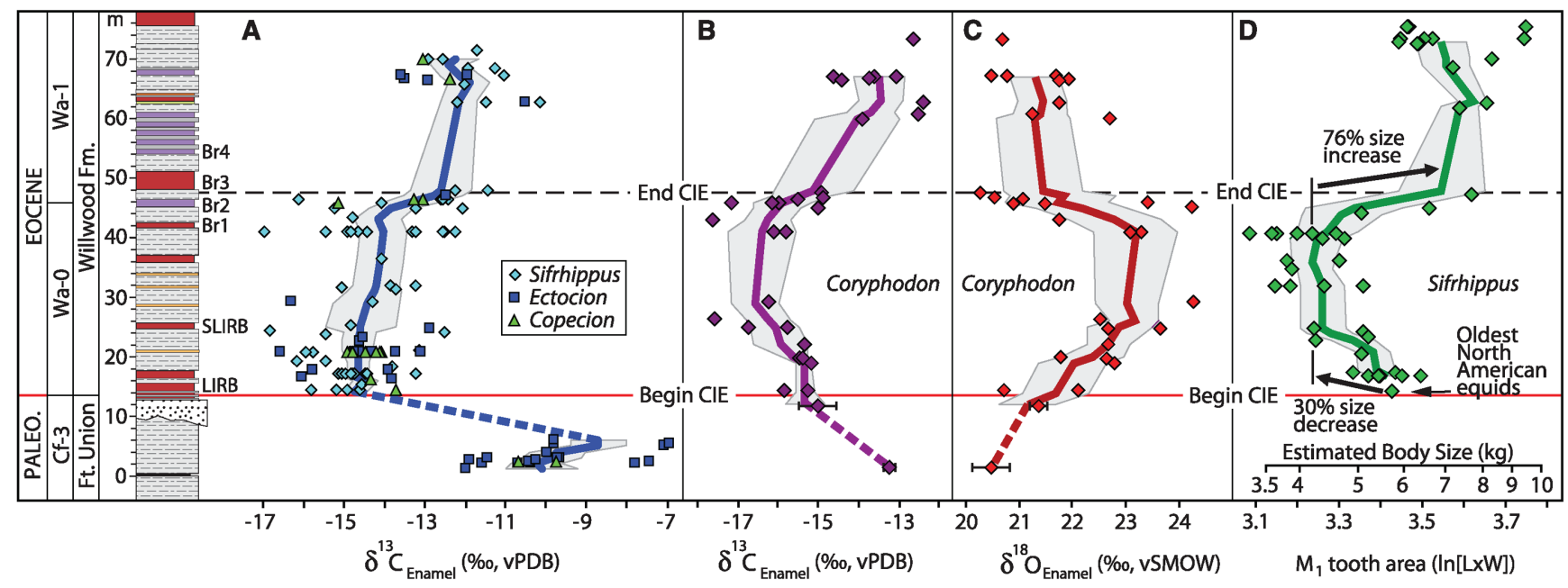

Figure 2. Comparison of PETM Cabin Fork records. (A) From left to right, epochs, mammalian biozones, formations, meter levels, marker beds, and $\delta^{13} C_{E}$ values for three common mammal genera. $V P D B$, Vienna Pee Dee belemnite standard. (B and $\left.\mathbf{C}\right) \delta^{13} C_{E}$ and $\delta^{18} O_{E}$ values for Coryphodon. vSMOW, Vienna standard mean ocean water standard. (D) Log-transformed measurements of first lower molar area (length $\times$ width) for Sifrhippus. Data points represent single individuals except where error bars (indicating $95 \%$ confidence of the mean for multiple samples from one individual) are shown. Solid colored lines show five-point moving averages; the gray area is the $95 \%$ envelope of uncertainty for each line. PALEO, Paleocene; Cf, Clarkforkian; Wa, Wasatchian. LIRB, SLIRB, and Br denote key marker beds.

Figure 3. Aridity and precipitation proxies. (A) Comparison of mean $\delta^{18} \mathrm{O}_{\mathrm{E}}$ values for aridity-insensitive Coryphodon (brown diamonds) and aridity-sensitive Sifrhippus (gold squares). Data are in 5-m bins. Brown circles are singletons of Coryphodon. (B) Aridity proxy curve based on (A), showing mean differences

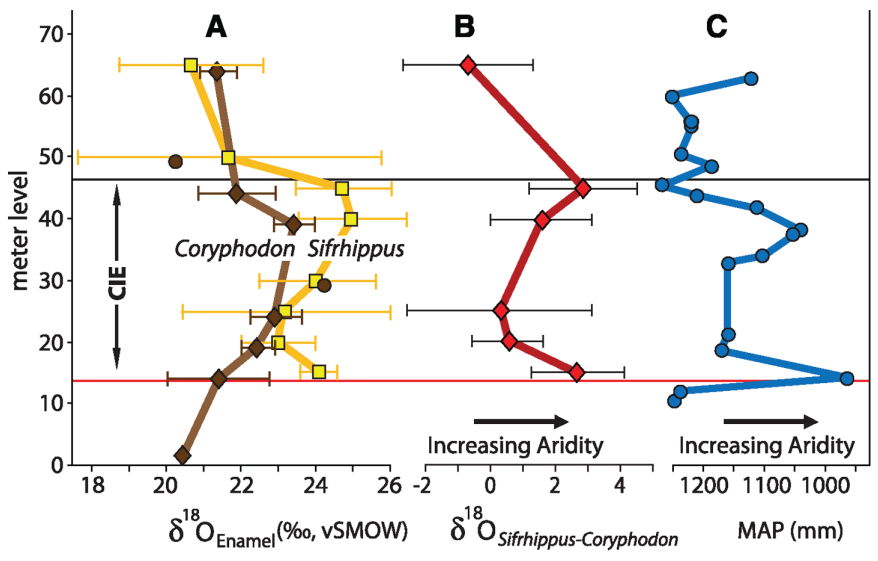

between Sifrhippus and Coryphodon $\delta^{18} \mathrm{O}_{\mathrm{E}}$. Greater difference implies greater aridity. Error bars show $95 \%$ confidence of the mean, offset in (A) by $1 \mathrm{~m}$ to avoid overlap. (C) MAP proxy based on paleosol major oxides from a nearby correlative section (HW16 section, SM).

its probable water dependence $(21,23)$, whereas Sifrhippus is the taxon most likely to be aridity-sensitive, because it has the highest average mammalian $\delta^{18} \mathrm{O}_{\mathrm{E}}$ value, suggesting that it consumed leaves in open areas where leaf water was evaporatively ${ }^{18} \mathrm{O}$-enriched. Increased aridity should result in higher Sifrhippus $\delta^{18} \mathrm{O}_{\mathrm{E}}$ values and greater separation between it and Coryphodon $\delta^{18} \mathrm{O}_{\mathrm{E}}$ (Figure 3A). Our second aridity proxy estimates mean annual precipitation (MAP) based on paleosol major oxides (Figure 3C and SM). Both proxies suggest drier conditions at the beginning of the CIE, followed by wetter conditions starting at $\sim 20 \mathrm{~m}(\sim 68 \mathrm{ky}$ into the PETM), with a return to drier conditions by $\sim 38 \mathrm{~m}(\sim 108 \mathrm{ky}$ into the PETM). Overall, there is poor agreement between Sifrhippus body size change and the aridity proxies. Both proxies indicate a shift to wetter conditions while body size in $\mathrm{Si}$ frhippus is decreasing, which is counter to expectations if the primary cause of dwarfing was lowered productivity caused by increased aridity.

Our results are consistent with mammalian dwarfing driven by warming, but temperature alone may be an insufficient explanation. Although body mass in living mammals is highly correlated with MAT in the Nearctic [coefficient of determination $\left.\left(R^{2}\right)=-0.75\right]$, this relationship weakens above $\sim 11^{\circ} \mathrm{C}$ and reverses (9). MAT was well above $\sim 11^{\circ} \mathrm{C}$ in the latest Paleocene and PETM of the Bighorn Basin (6). Furthermore, $\sim 25$ to $35 \%$ of living mammals deviate from Bergmann's rule $(8,9)$, and it is likely that at least some mammal lineages would have gotten larger during the PETM if MAT were the only controlling factor.

Another possible cause for body size decrease in the PETM is elevated atmospheric partial pressure of $\mathrm{CO}_{2}\left(\mathrm{PCO}_{2}\right)$ at higher temperatures in the Neotropics
(28), which might covary with temperature. In many extant plants, elevated $\mathrm{CO}_{2}$ increases biomass but reduces nitrogen and protein content in leaves and can elevate phenol levels, yielding cellulose-rich vegetation that is less nutritious and harder for herbivores to digest (29). Ultimately, this should result in slower growth and reproductive rates in herbivorous mammals (30), conceivably resulting in selection for smaller body size. Although this mechanism could have reduced body size in herbivores, size also decreased among PETM carnivores (Figure 1), which must be explained by an indirect response, such as selection for smaller predators because of smaller prey (31). Recent modeling of rates of carbon release during the PETM shows the largest increase in $\mathrm{PCO}_{2}$ at the onset of the CIE, followed by lower concentrations later in the event (2). This is inconsistent with a $\mathrm{PCO}_{2}$-driven decrease in body size, because Sifrhippus was smallest near the end of the main phase of the PETM. Although elevated $\mathrm{PCO}_{2}$ could have been a contributing factor, our results favor temperature as the primary driver of dwarfing in Sifrhippus.

PETM warming was similar in magnitude to that predicted by some global models over the next century (1) but occurred at a much slower rate and began from a warmer late Paleocene baseline. Nevertheless, some generalizations applicable to future warming may still be relevant. Diminished body size in some mammal species, along with changes in ecology and physiology, might be expected in response to warming. The pattern of dwarfing seen in the PETM mirrors recent reductions in body size in endotherms that have been attributed to anthropogenic warming $(10,12)$. Although the rate of present warming is 
much faster than during the PETM, and mammals may not respond in exactly the same manner, the dramatic response to warming observed in PETM equids provides a measure of possible responses to future warming in modern mammals.

\section{References and Notes}

1. Intergovernmental Panel on Climate Change (IPCC), Climate Change 2007 Synthesis Report (IPCC, Geneva, 2007).

2. Y. Cui et al., Nat. Geosci. 4, 481 (2011).

3. F. A. McInerney, S. L. Wing, Annu. Rev. Earth Planet. Sci. 39, 489 (2011).

4. G. J. Bowen, D. J. Beerling, P. L. Koch, J. C. Zachos, T. Quattlebaum, Nature 432, 495 (2004).

5. R. Secord, P. D. Gingerich, K. C. Lohmann, K. G. Macleod, Nature 467, 955 (2010).

6. S. L. Wing et al., Science 310, 993 (2005).

7. E. Mayr, Animal Species and Evolution (Harvard Univ. Press, Cambridge, MA, 1963).

8. K. G. Ashton, M. C. Tracy, A. de Queiroz, Am. Nat. 156, 390 (2000).

9. M. Á. Rodríguez, M. Á. Olalla-Tárraga, B. A. Hawkins, Glob. Ecol. Biogeogr. 17, 274 (2008).

10. J. L. Gardner, A. Peters, M. R. Kearney, L. Joseph, R. Heinsohn, Trends Ecol. Evol. 26, 285 (2011).

11. B. K. McNab, Oecologia 164, 13 (2010).
12. V. Millien et al., Ecol. Lett. 9, 853 (2006).

13. F. A. Smith et al., Global Planet. Change 65, 122 (2009).

14. P. D. Gingerich, Univ. Mich. Pap. Paleontol. 28, 1 (1989).

15. W. C. Clyde, P. D. Gingerich, Geology 26, 1011 (1998).

16. Numerous authors have shown the use of "Hyracotherium" to be invalid for North American equids. Thus, the species "Hyracotherium" sandrae (PETM) and "H." grangeri (post-PETM) were assigned to the new genera Sifrhippus Froelich 2002 and Arenahippus Froelich 2002, respectively. We found, however, that characters used to separate Sifrhippus from Arenahippus are highly variable and not useful for generic identification. Thus, we refer both species to Sifrhippus pending formal revision.

17. P. L. Koch, J. C. Zachos, P. D. Gingerich, Nature 358, 319 (1992).

18. F. A. Smith, S. L. Wing, K. H. Freeman, Earth Planet. Sci. Lett. 262, 50 (2007).

19. B. H. Passey et al., J. Archaeol. Sci. 32, 1459 (2005).

20. A. F. Diefendorf, K. E. Mueller, S. L. Wing, P. L. Koch, K. H. Freeman, Proc. Natl. Acad. Sci. U.S.A. 107, 5738 (2010).

21. R. Secord, S. L. Wing, A. Chew, Paleobiology 34, 282 (2008).

22. P. D. Gingerich, Genetica 112-113, 127 (2001).

23. M. T. Clementz, P. A. Holroyd, P. L. Koch,
Palaios 23, 574 (2008).

24. N. E. Levin, T. E. Cerling, B. H. Passey, J. M. Harris, J. R. Ehleringer, Proc. Natl. Acad. Sci. U.S.A. 103, 11201 (2006)

25. J. D. Bryant, P. N. Froelich, Geochim. Cosmochim. Acta 59, 4523 (1995).

26. W. Dansgaard, Tellus 16, 436 (1964).

27. M. J. Kraus, S. Riggins, Palaeogeogr. Palaeoclimatol. Palaeoecol. 245, 444 (2007).

28. P. D. Gingerich, Trends Ecol. Evol. 21, 246 (2006).

29. P. Stiling, T. Cornelissen, Glob. Change Biol. 13, 1823 (2007).

30. C. E. Owensby, R. C. Cochran, L. M. Auen, in Carbon Dioxide, Populations, and Communities, C. Koerner, F. Bazzaz, Eds. (Academic Press, San Diego, CA, 1996), pp. 363-371.

31. S. G. B. Chester, J. I. Bloch, R. Secord, D. M. Boyer, J. Mamm. Evol. 17, 227 (2010).

Acknowledgments - We thank T. Bown, P. Gingerich, B. MacFadden, K. Rose, E. Sargis, and S. Strait for helpful discussions and advice; J. Curtis, B. Tucker, and A. Baczynski for help with isotope lab work; J. Bourque and A. Hastings for specimen preparation; and P. Koch and two anonymous reviewers for helpful comments.

Supported by NSF grants EAR-0640076 (J.I.B. J.K. R.S.), EAR-0719941 (JI.B.), EAR0717892 (S.L.W.), EAR-0718740 (M.J.K.), and EAR-0720268 (F.A.M.). 


\section{Materials and Methods}

\section{Composite Lithostratigraphic Section Construction}

A composite lithostratigraphic section was constructed for fossil localities over a geographic area of $\sim 10 \mathrm{~km}^{2}$ collectively called Cabin Fork, for the Cabin Fork drainage of the southern Bighorn Basin, Wyoming. This composite section allowed fossil and geochemical data to be placed into a chronologic sequence. Local sections were correlated using several geographically extensive marker beds (Fig. 2A). Initially, most of these beds were identified in what we termed the "master section" in the "Prong Point" area of Cabin Fork (Fig. S1). Many of the diagnostic lithologic features of these marker beds were recognized at Prong Point, including, but not limited to, color, grain size, presence of paleosol nodules and/or ferruginous nodules, bed thickness, and thickness of intervals separating beds. Marker beds were physically traced from the master section and their 3-dimensional positions were recorded using a differential GPS. This allowed observation of which lithologic features were variable and which ones were more constant. With an understanding of the diagnostic features of single beds and sequences of beds in the master section, we were often able to identify particular marker beds prior to physically tracing them to the master section. In almost all regions of our collecting area are now connected by overlapping bed traces. Our collecting was later expanded to include higher and lower stratigraphic levels. Our "Highway 16" section (Fig. S1) includes the upper levels of the original master section as well as extensive stratigraphy above it.

Bed traces and localities were recorded using a high resolution differentially corrected GPS unit. Specifically we used a Trimble ProXRS in the early years of the 
project, and later switched to a Trimble GeoXT. Both units are rated for sub-meter accuracy in geographic coordinates using the WAAS signal and through real-time or post-processing corrections of satellite errors as compared to known base stations. Elevation reading accuracy is reportedly less than 2.5 meters. By repeatedly recording the same position from one year to the next over this seven year project we found that accuracy was usually at least as good as reported and in many cases it was even better in both geographic and elevational readings. Furthermore, elevational readings taken in the same recording session were often more accurate based on comparison with Jake-staff measured sections. GPS readings and Jake-staff measurements were highly correlated $\left(\mathrm{r}^{2}\right.$ $=0.99$ ) and were almost always in good agreement (Fig. S2) for stratigraphic position of individual beds and for total section thicknesses (often less than $25 \mathrm{~cm}$ difference). Thus, this system was exemplary for digitally recording the stratigraphic position of fossil localities relative to marker beds.

We treated stratigraphy of local sections as being flat-lying although on average a dip of 1-3 degrees was present. Error introduced was negligible compared to error in elevational GPS measurements.

Extensive bed tracing indicated dramatic changes in marker bed thickness as well as in the stratigraphic thickness separating marker beds. This means that absolute stratigraphic position of fossil localities relative to a single marker bed were often not meaningful in terms of the chronology of fossil localities from other parts of the field area (unless the fossil occurred at the very bottom of a marker bed). Therefore we converted stratigraphic distances to proportions (e.g., a locality's position is reported as above the top of $\mathrm{Br} 2$ by $20 \%$ the distance between $\mathrm{Br} 2$ and $\mathrm{Br} 3$ ). The limitation with this 
method is that localities can only be unambiguously placed if they are within a marker bed or if they are bracketed by at least two marker beds. However, in most cases data on bracketing beds was obtainable. Finally, relative stratigraphic positions of all localities were transformed into absolute meter levels shown in the composite section using marker bed levels in the master section as a base (Fig. 2A).

\section{$\underline{\text { Mean Annual Precipitation Estimates from Paleosols }}$}

The paleosols in a section near Wyoming Highway 16 (HW16 section), about 13 $\mathrm{km}$ northwest of the main Cabin Fork area, were used as a proxy for mean annual precipitation (MAP). The HW16 section was correlated to the CAB10 composite section (Fig. 2) using $\delta^{13} \mathrm{C}$ values in organic matter and marker beds. Location information for the paleosols is given in Table S1.

Quantitative estimates of MAP were calculated using the CALMAG weathering index of Nordt and Driese (1). This method, developed especially for Vertisols, is appropriate because the Willwood paleosols are paleo-Vertisols. If paleosols were thicker than $1 \mathrm{~m}$, the upper part of the B horizon was sampled at $10 \mathrm{~cm}$ vertical intervals for geochemical analysis (2). Fewer samples were collected from B horizons of thinner paleosols (<1 m thick). Samples were analyzed for major element oxides using a Kevex $0700 \mathrm{x}$-ray fluorescence spectrometer at the University of Colorado Laboratory for Environmental and Geological Studies (LEGS). Weight percents given by x-ray fluorescence $(\mathrm{XRF})$ were recalculated to molar percents for use in chemical weathering analyses. CALMAG was calculated for each of these samples, and MAP was calculated from the CALMAG values, following the approach of Nordt and Driese (1). For 
paleosols with multiple samples, the mean MAP value was calculated. Results are shown in Fig. 3C and Table S1.

\section{$\underline{\text { Age Model }}$}

The Willwood Formation consists of two facies: paleosols and heterolithic avulsion deposits. Moderately to strongly developed paleosols formed on mudrocks deposited by overbank flooding. The paleosols alternate vertically with the heterolithic deposits consisting of mudrocks, which show minimal paleosol development, and thin sandstones. The heterolithic deposits are interpreted to be ancient avulsion belt deposits that formed on the floodplain as the main channels were episodically abandoned in favor of new channel courses (3).

Limited pedogenic development indicates that the avulsion deposits accumulated very quickly compared to the paleosols, and this is supported by study of modern avulsion deposits (4). Consequently, we assigned $10^{3}$ years for each meter of avulsion deposit. The total time represented by avulsion deposits $\left(25 \times 10^{3}\right.$ years $)$ was subtracted from total time estimated for the CIE $\left(175 \times 10^{3} \mathrm{yr}\right)$, yielding $150 \times 10^{3} \mathrm{yr}$ for the total time represented by the eleven paleosols in the CIE interval (Table S2).

Various studies have used chronosequences to assess the profile development of Quaternary soils to soil age (5). These studies quantify particular morphologic features to generate an index that reflects the degree of soil development. Some features the indices use are not readily available to paleosol studies (e.g., moist and dry consistence). Other properties, such as color, are influenced by other soil-forming factors including climate and vegetation. More importantly, chronosequence studies analyze soils that develop in a 
top down manner, because the surface is stable and soil depth and the degree of alteration increase over time. In contrast, alluvial paleosols undergo what Johnson and WatsonStegner (6) termed regressive processes that impede soil development. Such processes include surface erosion and incorporation of new parent material at the top of the soil because of episodic floodplain deposition.

Because of the difficulties in developing a robust index of development for the Willwood paleosols, we used thickness of the B horizon as an estimate of the time represented by a particular paleosol. Focusing on the B horizon eliminates problems with erosion of all or part of the A horizon. The thickness of the B horizon reflects both downward migration of the lower soil boundary due to weathering of alluvium and upbuilding of the soil through time as a result of continued floodplain aggradation that was accompanied by pedogenesis. The thickness of the B horizon represents the length of time that sediment accumulation was slow and steady. For example, a $2 \mathrm{~m}$ thick B horizon indicates that the floodplain aggraded slowly over a relatively long time. Eventually, channel avulsion deposited several meters of sediment on top of the soil and that halted its development (3). In contrast, a 0.5 m thick B horizon represents slow floodplain accumulation for a commensurately shorter period of time before an avulsion event stopped its development.

Dividing $150 \times 10^{3} \mathrm{yr}$ by total thickness of the B horizons of the 11 paleosols in the interval $(8.65 \mathrm{~m})$, means that each meter of soil B horizon represents $\sim 17,341 \mathrm{yr}$ (Table S2). A time stratigraphic column was constructed using the stratigraphic position of each paleosol and avulsion deposit in the section and the time assigned to each paleosol and avulsion deposit (Table S3). The base of LIRB, which marks the base of the 
$\mathrm{CIE}$, is at $14.45 \mathrm{~m}$ in the section and at 0 years. The top of the CIE section is at the base of BR3 at the $48.05 \mathrm{~m}$ level in the section. It corresponds to a $175 \mathrm{x} 10^{3} \mathrm{yr}$ duration for the CIE in the time stratigraphic section.

\section{$\underline{\text { Moving Window Log-Rate-Interval Analysis (mwLRI) }}$}

Optimal binning search.-An exhaustive search was performed to find the binning scheme that optimized two criteria: (1) the maximum the number of time intervals with $\mathrm{N}>1$, and (2) the minimum number of intervals with $\mathrm{N}=1$. The search was conducted using an algorithm written in the R statistical computing package (7) that allowed the bin duration to vary from $0.2 \mathrm{kyr}$ to $50 \mathrm{kyr}$ at increments of $0.2 \mathrm{kyr}$. The beginning, or start value, of each binned series was also incrementally shifted forward by $0.2 \mathrm{ky}$ with the constraint that the first $\mathrm{M} / 1$ value of the morphological time series was always contained within the first bin, resulting in multiple binning schemes at each value of bin duration. For each set of binning schemes at a particular bin duration, the algorithm would report either the single scheme that optimized the above criteria, or, in the case of multiple, equivalently-optimized schemes, the binning scheme with the median start value. Out of the reported binning schemes, an $18.6 \mathrm{ky}$ binning scheme was chosen, providing 12 bins with $\mathrm{N}>1$ and 3 bins with $\mathrm{N}=1$ for a total of 15 time steps. The moving window LRI analysis was applied to this binned version of the $\mathrm{M} / 1$ crown area time series.

Description of moving window log-rate-interval method.-The moving window log-rate-interval (mwLRI) analysis is an extension of the standard LRI analysis of Gingerich (8) in which the relationship between rates of change and the lengths of 
intervals over which they are observed is used to investigate time series dynamics (i.e., patterns of directional trends and stable values). The LRI method is built on the observation that rates of change in a time series variable are often inversely proportional to the interval of time over which each rate is measured (8-11) which is primarily due to the occurrence of reversals in a given time series. It should be noted here that this relationship holds true regardless of whether the interval length is measured in time or depth. Thus, the phrase "time series" is used here to refer to variables measured over either numerical time or stratigraphic depth.

In an LRI analysis, all possible pairwise rates of change are regressed onto the corresponding interval of time and a slope is calculated for the regression line. The steepness of the negative slope reflects the amount of reversals present in a time series, such that a directional time series with few reversals would produce $\mathrm{a} \sim 0$ slope value and a stable time series with many reversals would produce a slope value near -1 . The expected slope value for an unbiased, random walk is -0.5 , but actual slope values derived from random walks can vary anywhere between 0 to -1 .

The mwLRI analysis includes two additions to the standard LRI method. First, the observed slopes in each mwLRI analysis are compared to distributions of slopes generated using Monte Carlo simulations of a random walk. This is done in order to reject a null hypothesis of a random time series and unequivocally determine if the observed time series exhibits directional change or stability. Each Monte Carlo simulation starts with the initial time step of the observed time series and randomly adds or subtracts a value from a uniform distribution that ranges from minimum to the maximum observed differences between consecutive steps in the observed series. 
Choosing from such a uniform distribution constrains the amount of change possible between consecutive steps in the random walk to be similar to that of the observed time series. The number of time steps in the resulting random walk is equal to that of the observed time series. If the observed slope falls outside and above confidence intervals of slopes produced by random walks, the observed time series can be interpreted as exhibiting directional change. An observed slope outside and below a given confidence interval is indicative of a stable time series.

The second addition to the standard LRI method is that a mwLRI analysis performs a heuristic search for shift points in time series dynamics (i.e., changes in directionality or mode). A standard LRI analysis of a time series with heterogeneous dynamics requires a priori hypotheses concerning when changes in directionality or mode take place. The heuristic search approach of the mwLRI method avoids this prerequisite by calculating an LRI slope for all possible subsets of the observed time series, allowing each slope and its statistical significance to be interpreted within the context of all other subset results. Operationally, this is performed by calculating an observed LRI slope and a distribution of random walk slopes in a window that varies from a minimum of 5 steps to the length of the entire series. After each calculation, the test window shifts one step forward in the time series and performs a new set of calculations. Once all possible consecutive subsets are tested at a given window size, the window size increases by one step, and the process is reiterated. A minimum window size of 5 time steps was chosen to provide at least 10 points for the slope calculation.

Result "maps" in which LRI results for subsets are organized by initial time step and window size (Fig. S3) provide a useful way of applying mwLRI results to a final 
interpretation of dynamics in the observed time series. A long subset of homogeneous dynamics (e.g., a long directional trend) in a time series analyzed in windows smaller than or equal to the length of the homogenous subset is likely to produce nested and similar slope and significance values, appearing as a cluster of similar results on the map. For consistency, only the value with the greatest window size is reported in the final interpretation. Temporally adjacent subsets exhibiting different time series dynamics are likely either to overlap or be separated by a series of time steps that cannot be distinguished from a random walk. In these cases, the midpoint of the overlap or random subset is interpreted as the shift point in the observed time series dynamics.

The version of the mwLRI analysis used here was performed using an R script that is available upon request. Results for our analysis of Sifrhippus are shown in Fig. S4.

\section{$\underline{\text { Regression Analyses }}$}

We used ordinary least squares linear regression to determine if relationships existed among Sifrhippus first lower molar (M/1) size, Coryphodon $\delta^{18} \mathrm{O}$ values, and Sifrhippus $\delta^{18} \mathrm{O}$ values. The Durbin-Watson statistic was used to test for serial correlation (autocorrelation) in the datasets, which is sometimes present in time series (12-16). When serial correlation is present, the regression errors (residuals) are correlated with themselves lagged by one or more units. Serial correlation violates the assumption of independence. Positive serial correlation results in an underestimate of the error variance resulting in a lower probability ( $P$-value) estimate and an overly optimistic conclusion, while negative serial correlation tends to overestimate the error variance. We used the Durbin-Watson statistic (DW) to test for first order serial correlation in the regression residuals. The Durbin-Watson test uses the difference between successive regression 
residuals to approximate the amount of serial correlation present $(17,18)$. DW values range from 0 to 4 . A value of 2 indicates the absence of serial correlation, while values of 0 and 4 indicate strong positive and negative serial correlation, respectively. Upper and lower critical values have been calculated for the Durbin-Watson statistic based on sample size and the number of independent variables in the regression (13). If DW is greater than the upper critical value, the null hypothesis of serial correlation can be rejected with $95 \%$ confidence. If it is below the lower critical value, serial correlation is probably present. If it falls between critical values, the presence of serial correlation is uncertain. We also used the Shapiro-Wilk test for normality of distribution, assuming that samples with $P \geq 0.05$ were normally distributed.

Data were placed in stratigraphic bins to test for correlation. In order to determine whether correlation was sensitive to binning schemes we conducted correlation tests using 4, 5, and 6 meter bin sizes, and shifted the starting points for each bin by a meter. Results are summarized in Tables S6, S7, and S8. Sifrhippus M/1 area is strongly correlated with Coryphodon $\delta^{18} \mathrm{O}_{\mathrm{E}}$ values (Table S4). Correlation is significant with $95 \%$ confidence for all in all cases, indicating that the correlation is not sensitive to binning. For all 5-meter bins and all but one 6-meter bin the DW statistic indicates that the influence of first order autocorrelation can be rejected. For two or four 4-meter bins and one 6-meter bin the DW statistic falls into the uncertain range. This is of little concern, however, given the indicated absence of autocorrelation for the large majority of bins. The Shapiro Wilk statistic indicates that the distribution of data does not differ significantly from normal for all bins. Thus, we conclude that this is a robust correlation 
and there is a strong relationship between Sifrhippus M/1 area and Coryphodon $\delta^{18} \mathrm{O}_{\mathrm{E}}$ values (Table S4).

Regression of Sifrhippus M/1 area on Sifrhippus $\delta^{18} \mathrm{O}_{\mathrm{E}}$ values yielded mixed results (Table S5). The significance of the correlation is dependent to some extent on the starting point of the bin. Also problematic, the in seven of fifteen cases the DW statistic falls in the range of uncertainty, indicating that the influence of autocorrelation cannot be confidently rejected, although in no case does the statistic fall below the critical lower value. The problem seems to be worse with smaller bin sizes. Also, in several cases, distributions differ significantly from normal according to the Shapiro-Wilk statistic. When these cased were tested with rank-order tests, none was significant. Thus, this correlation is marginal. This is not especially surprising since oxygen isotopes in taxa that consume leaf water are expected to be more variable than in those that are insensitive to aridity. As discussed in the main text, Sifrhippus is the most likely of the common PETM taxa to have been aridity sensitive, and changes in its body size do not appear to be correlated with aridity.

Faunal (Ectocion, Copecion, Sifrhippus) $\delta^{13} \mathrm{C}_{\mathrm{E}}$ values are significantly correlated with Coryphodon $\delta^{18} \mathrm{O}$ values in all but one case, which is marginally significant $(P=$ 0.54). Thus, this relationship is not dependent on binning scheme. Also, the possibility of influence from first order autocorrelation can be reject in all cases, based on the DW statistic. The Shapiro-Wilk statistic does indicate deviation from normality in four of fifteen cases in the 4-meter and 5-meter binning schemes (Table S6). When Spearman's non-parametric rank order test is applied only one of these cases (4-meter bin, start 0) remains significant with $95 \%$ confidence $(P=0.043$; others $0.099,0.108,0.214)$. 
Nevertheless, in all cases but one that pass the Shapiro Wilk test the correlation is significant. Thus, there appears to be a relationship between faunal $\delta^{13} \mathrm{C}_{\mathrm{E}}$ values and Coryphodon $\delta^{18} \mathrm{O}_{\mathrm{E}}$ values. This may be expected if Coryphodon $\delta^{18} \mathrm{O}_{\mathrm{E}}$ values were tracking temperature changes caused by $\mathrm{CO}_{2}$ forcing, which would be reflected in the shift to more negative $\delta^{13} \mathrm{C}_{\mathrm{E}}$ values as massive amounts of isotopically ${ }^{13} \mathrm{C}$-depleted $\mathrm{CO}_{2}$ were released to the atmosphere during the CIE. However, although few would argue that $\mathrm{CO}_{2}$ forcing from highly $\mathrm{C}^{13}$-depleted carbon released during the PETM was an important factor in warming during the PETM, alone it may not have been sufficient to explain the full magnitude of inferred warming (19).

\section{Estimates of Mammalian Body Mass}

Previous work has shown a strong correlation between molar size and long bone length (used only for Palaeanodon), and body mass in extant mammals (20-28). We used primarily equations provided by Legendre (20) to calculate percent changes in body mass for PETM taxa (Table S7). Many of these species are known from only a small number of fragmentary specimens, and individual estimates could change considerably with additional material and further taxonomic study. Locomotor behavior in Table S7 is speculative for some taxa. Notably, no postcrania are known for Arctodontomys and arboreality is assumed because other plesiadapiform primates for which postcrania are known are arboreal. Rose (29) suggested that Arfia was cursorial/scansorial. Vassacyon was assumed to be arboreal by Heinrich and Houde (30). Hyopsodus postcrania are not well known from the Wasatchian, but the postcrania of younger species suggest that it was a generalist, with some characters suggesting terrestriality and others suggesting the 
ability to climb trees or dig (31). Azygonyx also exhibits a mosaic of terrestrial and arboreal postcranial characters (29).

Stratigraphic data for Sifrhippus, the most abundantly represented PETM genus in the Cabin Fork area, are shown in Table S8. Equid teeth were carefully examined to insure that no deciduous juvenile teeth were included. We used juvenile specimens with deciduous teeth to aid in identification of tooth position, and also considered the degree of wear to ensure that all teeth included in Table S8 belonged to adults.

\section{$\underline{\text { Stable Isotope Analysis }}$}

Isotope ratios are expressed in delta notation as parts per thousand (\%) relative to a standard: $\delta^{18} \mathrm{O}$ or $\left.\delta^{13} \mathrm{C}=\left(\left[\mathrm{R}_{\text {sample }} / \mathrm{R}_{\text {standard }}\right]-1\right)\right) \times 10^{3}$, where $\mathrm{R}={ }^{18} \mathrm{O} /{ }^{16} \mathrm{O}$ for oxygen, relative to vSMOW (Vienna standard mean ocean water), and $\mathrm{R}={ }^{13} \mathrm{C} /{ }^{12} \mathrm{C}$ for carbon, relative to vPDB (Vienna PeeDee Belemnite).

Oxygen and carbon stable isotopes ratios were measured from the carbonate component of mammalian tooth enamel (hydroxylapatite). Samples weighing 3-4 mg were drilled from teeth using a Brassler dental drill with a $1 \mathrm{~mm}$ diamond burr mounted under a binocular microscope in the Bone Chemistry Laboratory in the Department of Anthropology at the University of Florida. Samples were then pretreated with 2-3\% sodium hypochlorite and $1 \mathrm{M}$ acetic acid buffered with calcium acetate to remove organic matter and non-structural carbonate following the recommendations of Koch et al. (32). Our protocol differed only in that samples were roasted after pretreatment at $200{ }^{\circ} \mathrm{C}$ under vacuum for 1 hour to remove volatile contaminants and water, rather than being lyophilized (33). 
Stable isotope ratios were measured in the Light Stable Isotope Mass Spec Lab (LSIMSL) at the University of Florida in the Department of Geological Sciences. The first two batches of enamel (SB1 and SB2) were analyzed using a VG / Micromass PRISM Series II isotope ratio mass spectrometer with an Isocarb common acid bath preparation device. Samples were loaded into stainless steel boats and placed into a 44position Isocarb preparation system. Samples were reacted in a common acid bath in orthophosphoric acid at $90^{\circ} \mathrm{C}$ and water was cryogenically removed in a methanol slush. Evolved $\mathrm{CO}_{2}$ gas was measured online with the VG / Micromass PRISM Series II isotope ratio mass spectrometer. Analytical precision is generally better than $\pm 0.1 \%$ for $\delta{ }^{13} \mathrm{C}$ and $0.1 \%$ for $\delta^{18} \mathrm{O}$ at LSIMSL for the international standard NBS-19. Reported error in this section is one standard deviation (SD). Eight standards were run with each thirty-six research samples. Intralab enamel standards of LOX (modern African elephant enamel) and MES (mammoth fossil enamel) were also analyzed with each batch. These standards yielded the following values for the acid bath: $\operatorname{LOX} \delta^{13} \mathrm{C}=-5.8 \pm 0.04 \%, \delta^{18} \mathrm{O}=$ $30.7 \pm 0.09 \%$ o $(\mathrm{n}=8)$; $\operatorname{MES} \delta^{13} \mathrm{C}=-9.8 \pm 0.07 \%$, $\delta^{18} \mathrm{O}=22.4 \pm 0.10 \%$ o $(\mathrm{n}=7)$.

The remaining batches were analyzed using a Finnigan-MAT 252 isotope ratio mass spectrometer coupled with a Kiel III carbonate preparation device. Oxygen and carbon isotopes were measured by reacting samples in orthophosphoric acid at $70^{\circ} \mathrm{C}$ using a Finnigan-MAT Kiel III carbonate preparation device. Evolved $\mathrm{CO}_{2}$ gas was measured online with a Finnigan-MAT 252 mass spectrometer. Analytical precision for isotope analyses is generally better than $\pm 0.05 \%$ for $\delta{ }^{13} \mathrm{C}$ and $0.10 \%$ for $\delta{ }^{18} \mathrm{O}$ for the NBS-19 standard at LSIMSL. Our enamel standards yielded: $\operatorname{LOX} \delta^{13} \mathrm{C}=-5.8 \pm 0.06 \%$, $\delta^{18} \mathrm{O}=31.2 \pm 0.09 \%$ ( $\left.\mathrm{n}=12\right) ; \operatorname{MES} \delta^{13} \mathrm{C}=-9.9 \pm 0.09 \%, \delta^{18} \mathrm{O}=22.6 \pm 0.17 \%$ o $(\mathrm{n}=29)$. 
Differences between samples run on the PRISM Series II (acid bath) and Finnigan-MAT 252 (Kiel) ranged from 0.05 to $0.13 \%$ (LOX and MES, respectively) for enamel $\delta^{13} \mathrm{C}$, and 0.52 to $0.20 \%$ (LOX and MES, respectively) for enamel $\delta^{18} \mathrm{O}$. While the difference in $\delta^{13} \mathrm{C}$ for MES was significant $(P<0.001)$ it is trivial at the scale at which we are working and no correction was made. The differences in $\delta^{18} \mathrm{O}$ were greater, especially for LOX, and both were significant $(P<0.001)$. These differences appear to scale with a greater difference at the higher $\delta^{18} \mathrm{O}$ values for LOX. Assuming the relationship is linear, a correction factor would be $\delta^{18} \mathrm{O}_{\text {Kiel }}=\delta^{18} \mathrm{O}_{\text {Acid-Bath }} \times 1.038$ - 0.6507. Because our $\delta^{18} \mathrm{O}$ values for Bighorn Basin enamel are most similar to those of the MES standard, this correction results in only a small difference (average $=-0.20 \%$ ). This difference is minor for the scale at which we are working and only slightly more than one standard deviation for the MES standard for the Kiel $( \pm 0.17 \% ; n=29)$. Therefore we refrained from making a correction. Values for our Bighorn Basin fossil material are reported in Table S9. 


\section{References}

1. L. C. Nordt, S. D. Driese, Geology 38, 407 (2010).

2. S. G. Driese, Journal of Geology 112, 543 (2004).

3. M. J. Kraus, B. Gwinn, Sedimentary Geology 114, 33 (1997).

4. N. D. Smith, T. A. Cross, J. P. Dufficy, S. R. Clough, Sedimentology 36, 1 (1989).

5. J. W. Harden, Geoderma 28, 1 (1982).

6. D. L. Johnson, D. Watson-Stegner, Soil Science 143, 349 (1987).

7. R_Development_Core_Team, 2011, http://www.R-project.org.

8. P. D. Gingerich, American Journal of Science 293A, 453 (1993).

9. W. C. Clyde, P. D. Gingerich, Paleobiology 20, 506 (Fal, 1994).

10. P. D. Gingerich, Genetica 112-113, 127 (2001).

11. P. D. Gingerich, Annual Review of Ecology, Evolution, and Systematics 40, 657 (2009).

12. R. H. Shumway, Applied statistical time series analysis. (Prentice Hall, New Jersey, 1988), pp. 379.

13. R. H. Shumway, D. S. Stoffer, Time series analysis and its applications. (Springer-Verlag, New York, 2000), pp. 549.

14. M. L. McKinney, in Evolutionary trends, K. J. McNamara, Ed. (The University of Arizona Press, Tucson, 1990), pp. 28-58.

15. J. J. F. Commandeur, S. J. Koopman, An introduction to state space time series analysis. J. Doornik, B. Hall, Eds., (Oxford University Press, Oxford, 2007), pp. 174. 
16. R. Secord, Papers on Paleontology 35, 1 (2008).

17. T. H. Wonnacott, R. J. Wonnacott, Introductory statistics for business and economics. (John Wiley and Sons, New York, ed. Second edition, 1977), pp. 753.

18. E. B. Andersen, N.-E. Jensen, N. Kousgaard, Statistics for economics, business administration, and the social sciences. (Springer-Verlag, Berlin, 1987), pp. 439.

19. R. E. Zeebe, J. C. Zachos, G. R. Dickens, Nature Geoscience 2, (2009).

20. S. Legendre, Palaeovertebrata 16, 191 (1986).

21. S. Legendre, Revue de Paléobiologie 6, 183 (1987).

22. P. D. Gingerich, American Journal of Physical Anthropology 47, 395 (1977).

23. P. D. Gingerich, B. H. Smith, K. Rosenberg, American Journal of Physical Anthropology 52, 231 (1980).

24. P. D. Gingerich, B. H. Smith, K. Rosenberg, American Journal of Physical Anthropology 58, 81 (1982).

25. J. Damuth, B. J. MacFadden, Eds., Body size in mammalian paleobiology: estimation and biological implications, (Cambridge University Press, Cambridge, 1990), pp. 397.

26. M. Mendoza, C. M. Janis, P. Palmqvist, Journal of Zoology 270, 90 (2006).

27. P. D. Gingerich, Journal of Paleontology 48, 895 (1974).

28. B. J. MacFadden, Paleobiology 12, 355 (1986).

29. K. D. Rose, in Paleocene-Eocene stratigraphy and biotic change in the Bighorn and Clarks Fork basins, Wyoming, P. D. Gingerich, Ed. (University of Michigan Papers on Paleontology 33, 2001), vol. 33,pp. 157-183.

30. R. E. Heinrich, P. Houde, Journal of Vertebrate Paleontology 26, 422 (2006). 
31. K. D. Rose, The beginning of the age of mammals. (The Johns Hopkins University Press, Baltimore, 2006), pp. 428.

32. P. L. Koch, N. Tuross, M. L. Fogel, Journal of Archaeological Science 24, 417 (1997).

33. R. Secord, P. D. Gingerich, K. C. Lohmann, K. G. MacLeod, Nature 467, 955 (2010).

34. P. D. Gingerich, University of Michigan Papers on Paleontology 28, 1 (1989). 

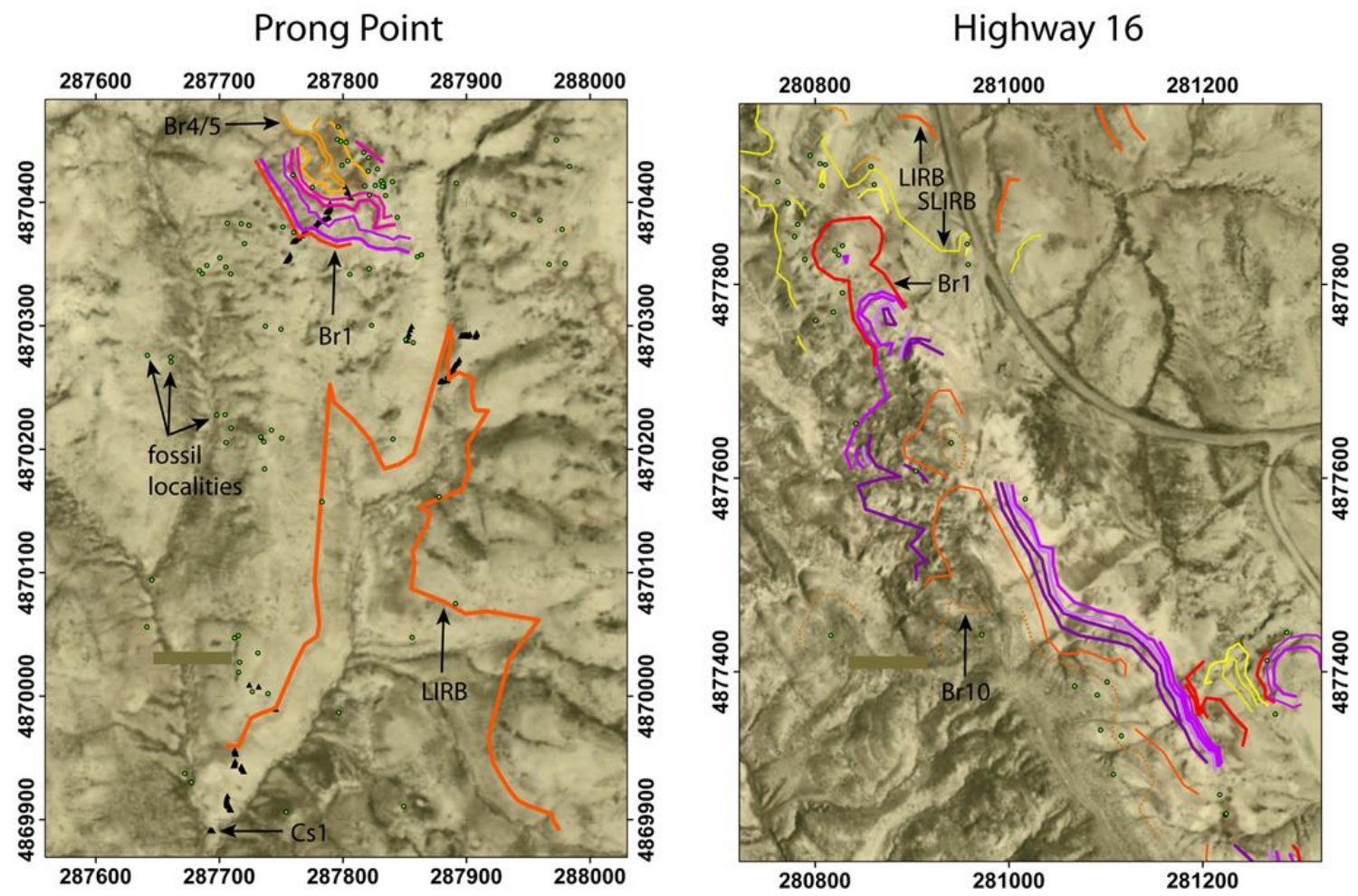

Fig. S1. Two maps showing marker bed traces in the region of our "master sections" that provide the meter levels reported in Fig. 2A. Easting and Westing coordinates are UTM's based on NAD 27 datum, Zone 13N. Colored lines indicate marker beds. Green dots represent fossil localities. Black triangles represent sample sites for geochemical analyses. Stratigraphic position was calculated using traditional Jake-staff methods as well as with differentially corrected GPS measurements. Marker beds LIRB, SLIRB, Br1, and Br4, are shown in stratigraphic sequence in Fig. 2. 


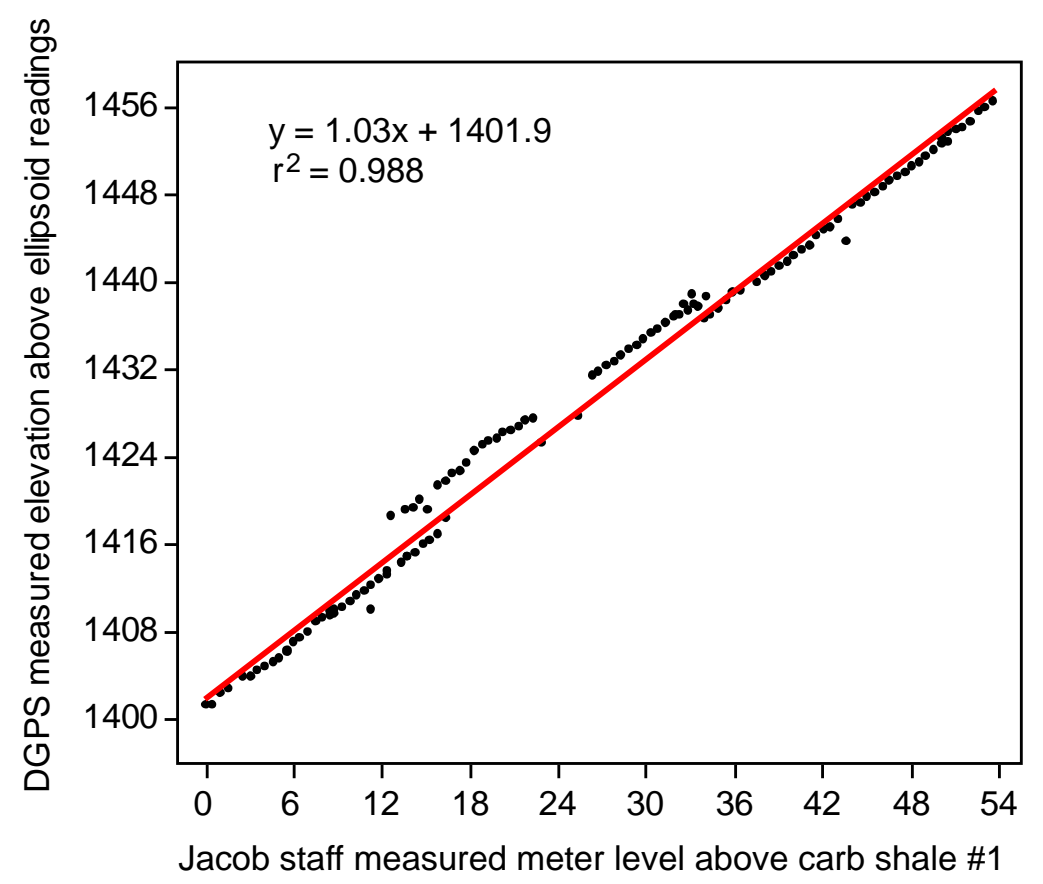

Fig. S2. Comparison of Jacob staff measurements with DGPS (Trimble ProXRS) readings. Localities whose elevations are shown here are represented by black triangles in Fig. S1, left image. Note strong correlation. Most readings were taken roughly along strike of local bedding that dips west-south-west. However, sample sites between 12 to $33 \mathrm{~m}$ are from local sections slightly up dip (black triangles farther to right in Fig. S1). Accordingly, the DGPS records slightly higher elevations for same bed, whereas the Jacob staff measurements have accounted for dip. 
A

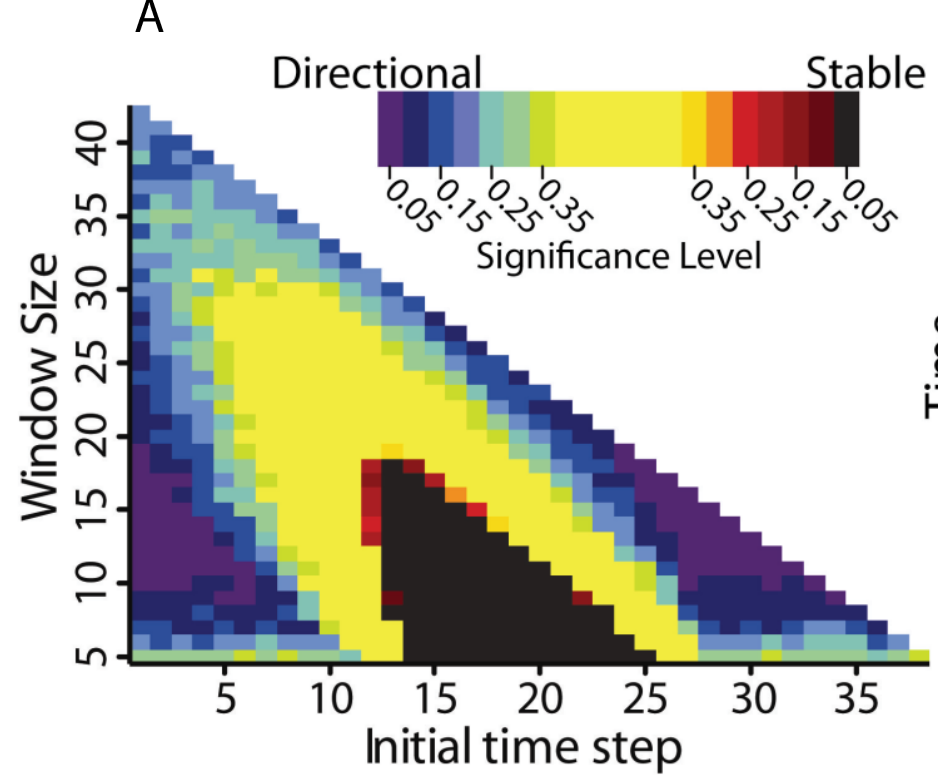

B

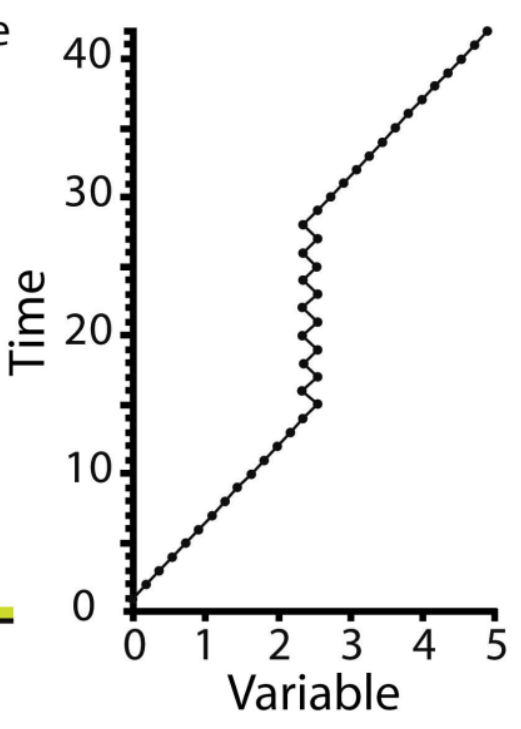

Fig. S3. Moving window LRI results for a hypothetical evolutionary time series in which two directional subsets are separated by a subset of stable values. A, colored boxes correspond to significance levels for directional, random, or stable trends. "Initial step" indicates starting point of moving window of variable size (y-axis). For example, the interval with an initial step of 3 and a window size of 12 indicates a directional trend with 95\% confidence (purple). B, variable (e.g., first molar area) plotted against time. The result map (A) shows 3 clusters of $95 \%$ significant results associated with the two directional subsets (purple clusters) and the single stable subset (black cluster). Nonsignificant results outside of these clusters correspond to subsets of the hypothetical time series in which directional and stable patterns are mixed (e.g., time steps 10-24 or initial step 10/window size 15 in the result map). The results with the largest window size in each cluster indicate: (1) directional change from time steps 1-19, (2) stable values from time steps 13-30, and (3) directional change from time steps 24-42. Taking the midpoint of the two overlaps provides a final interpretation of the mwLRI results: directional 
change between steps 1-16, stable values between steps 16-27, and directional change from steps $27-42$. 
A

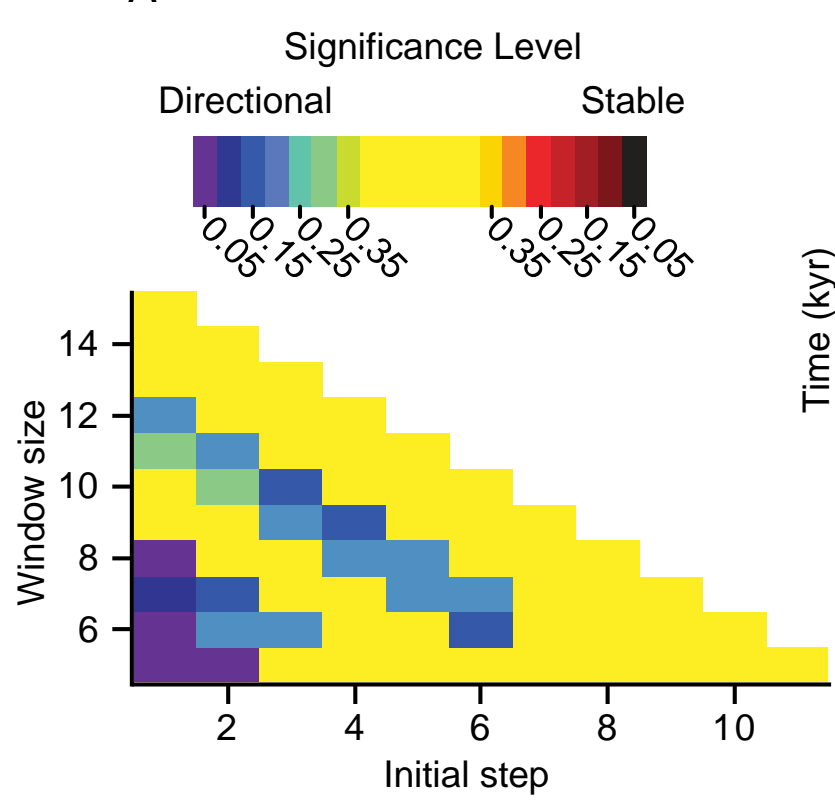

B $\mathrm{m} / 1$ - $18.6 \mathrm{kyr}$ bins

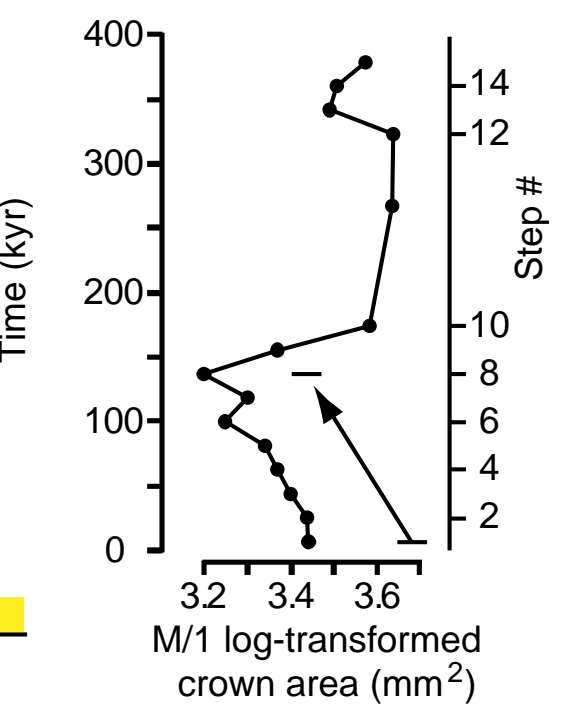

Fig. S4. Moving window LRI results of evolutionary trends in Sifrhippus through composite section at Cabin Fork. (A) result map of significance levels for directional, random, or stable trends. (B) Mean values of binned (-18.6 kyr bins), log-transformed, first molar area plotted against time model. Results indicate a directionally decreasing trend over steps 1-8 ( 9-139 kyr interval). 
Table S1. Paleosol data from Highway 16 section used to estimate mean annual precipitation. Mean values shown in boxes.

\begin{tabular}{|c|c|c|c|c|c|c|c|c|c|}
\hline Trench & $\begin{array}{l}\text { Strat } \\
\text { Level }\end{array}$ & CALMAG & $\begin{array}{c}\text { CALMAG } \\
\text { MAP }\end{array}$ & $\begin{array}{l}\mathrm{MgO} \\
\mathrm{wt} \%\end{array}$ & $\begin{array}{l}\mathrm{CaO} \\
\mathrm{wt} \%\end{array}$ & $\begin{array}{l}\mathrm{Al}_{2} \mathrm{O}_{3} \\
\mathrm{wt} \%\end{array}$ & $\begin{array}{c}\text { molar } \\
\mathrm{CaO}\end{array}$ & $\begin{array}{l}\text { molar } \\
\mathrm{Al}_{2} \mathrm{O} 3\end{array}$ & $\begin{array}{c}\text { molar } \\
\text { MgO }\end{array}$ \\
\hline HW16-08-15 & \multirow[t]{3}{*}{64.0} & 65.06 & 1040 & 1.90 & 2.33 & 16.86 & 0.042 & 0.165 & 0.047 \\
\hline N44우 $01.087^{\prime}$ & & \multirow[t]{2}{*}{72.34} & 1206 & \multirow[t]{2}{*}{1.92} & \multirow[t]{2}{*}{0.84} & \multirow[t]{2}{*}{16.7} & \multirow[t]{2}{*}{0.015} & \multirow[t]{2}{*}{0.164} & \multirow[t]{2}{*}{0.048} \\
\hline$W 107^{\circ} 43.864^{\prime}$ & & & 1123 & & & & & & \\
\hline HW16-08-14 & 61.0 & 75.41 & 1275 & 1.92 & 0.61 & 18.26 & 0.011 & 0.179 & 0.048 \\
\hline N44우 01.116' & & 74.80 & 1261 & 1.89 & 0.54 & 17.06 & 0.010 & 0.167 & 0.047 \\
\hline \multirow[t]{4}{*}{$W 107^{\circ} 43.887^{\prime}$} & & 75.78 & 1284 & 1.71 & 0.51 & 16.40 & 0.009 & 0.161 & 0.042 \\
\hline & & 72.38 & 1206 & 1.92 & 0.84 & 16.70 & 0.015 & 0.164 & 0.048 \\
\hline & & \multirow[t]{2}{*}{73.95} & 1242 & \multirow[t]{2}{*}{1.73} & \multirow[t]{2}{*}{0.50} & \multirow[t]{2}{*}{14.95} & \multirow[t]{2}{*}{0.009} & \multirow[t]{2}{*}{0.147} & \multirow[t]{2}{*}{0.043} \\
\hline & & & 1254 & & & & & & \\
\hline HW16-08-12 & 56.8 & 72.89 & 1218 & 1.99 & 0.59 & 16.42 & 0.011 & 0.161 & 0.049 \\
\hline upper paleosol & & 73.21 & 1225 & 1.93 & 0.55 & 16.08 & 0.010 & 0.158 & 0.048 \\
\hline N44우 01.117' & & & 1222 & & & & & & \\
\hline \multicolumn{10}{|l|}{$W 107^{\circ} 43.881^{\prime}$} \\
\hline HW16-08-12 & 56.02 & 72.84 & 1217 & 2.05 & 0.58 & 16.74 & 0.010 & 0.164 & 0.051 \\
\hline \multirow[t]{2}{*}{ lower paleosol } & & \multirow[t]{2}{*}{73.33} & 1228 & \multirow[t]{2}{*}{1.87} & \multirow[t]{2}{*}{0.7} & \multirow[t]{2}{*}{16.51} & \multirow[t]{2}{*}{0.012} & \multirow[t]{2}{*}{0.162} & \multirow[t]{2}{*}{0.046} \\
\hline & & & 1223 & & & & & & \\
\hline HW16-08-08 & 51.53 & 74.51 & 1255 & 1.59 & 0.6 & 14.95 & 0.011 & 0.147 & 0.039 \\
\hline N44우 01.126' & & 74.49 & 1254 & 1.67 & 0.67 & 15.87 & 0.012 & 0.156 & 0.041 \\
\hline \multirow[t]{4}{*}{$W 107^{\circ} 43.863^{\prime}$} & & 72.72 & 1214 & 1.50 & 1.01 & 15.01 & 0.018 & 0.147 & 0.037 \\
\hline & & 73.35 & 1228 & 1.72 & 0.79 & 15.93 & 0.014 & 0.156 & 0.043 \\
\hline & & \multirow[t]{2}{*}{74.31} & 1250 & \multirow[t]{2}{*}{1.73} & \multirow[t]{2}{*}{0.72} & 16.42 & 0.013 & 0.161 & 0.043 \\
\hline & & & 1240 & & & & & & \\
\hline HW16-08-07 & 49.6 & 72.93 & 1219 & 1.53 & 0.96 & 15.13 & 0.017 & 0.148 & 0.038 \\
\hline $\mathrm{N} 44^{\circ} 01.131^{\prime}$ & & 71.10 & 1177 & 1.54 & 1.30 & 15.40 & 0.023 & 0.151 & 0.038 \\
\hline$W 107^{\circ} 43.852^{\prime}$ & & 69.97 & 1152 & 1.56 & 1.54 & 15.70 & 0.027 & 0.154 & 0.039 \\
\hline & & 72.54 & 1210 & 1.77 & 0.98 & 16.54 & 0.017 & 0.162 & 0.044 \\
\hline & & 71.40 & 1190 & 1.78 & 1.22 & 16.80 & 0.022 & 0.165 & 0.044 \\
\hline & & & 1190 & & & & & & \\
\hline HW16-08-06 & 46.45 & 74.78 & 1261 & 1.72 & 0.68 & 16.57 & 0.012 & 0.163 & 0.043 \\
\hline
\end{tabular}




$\begin{array}{llllllll}75.28 & 1272 & 1.63 & 0.64 & 16.12 & 0.011 & 0.158 & 0.041 \\ 75.17 & 1270 & 1.65 & 0.66 & 16.27 & 0.012 & 0.160 & 0.041 \\ 75.10 & 1268 & 1.65 & 0.72 & 16.54 & 0.013 & 0.162 & 0.041 \\ 75.70 & 1282 & 1.64 & 0.70 & 16.89 & 0.012 & 0.166 & 0.041 \\ & 1271 & & & & & & \end{array}$

\begin{tabular}{|c|c|c|c|c|c|c|c|c|c|}
\hline HW16-08-05 & 44.8 & 72.28 & 1204 & 1.90 & 0.72 & 15.93 & 0.013 & 0.156 & 0.047 \\
\hline $\mathrm{N} 44^{\circ} 01.114^{\prime}$ & & 72.97 & 1220 & 1.76 & 0.74 & 15.67 & 0.013 & 0.154 & 0.044 \\
\hline \multirow[t]{4}{*}{ W107 $43.833^{\prime}$} & & 72.72 & 1214 & 1.79 & 0.76 & 15.76 & 0.013 & 0.155 & 0.045 \\
\hline & & 72.79 & 1216 & 1.85 & 0.74 & 16.12 & 0.013 & 0.158 & 0.046 \\
\hline & & 72.73 & 1214 & 1.78 & 0.79 & 15.86 & 0.014 & 0.156 & 0.044 \\
\hline & & & 1214 & & & & & & \\
\hline
\end{tabular}

\begin{tabular}{|c|c|c|c|c|c|c|c|c|c|}
\hline HW16-08-02 & 42.74 & 70.85 & 1172 & 1.76 & 0.97 & 15.08 & 0.017 & 0.148 & 0.044 \\
\hline N44우 $01.128^{\prime}$ & & 70.01 & 1153 & 2.00 & 0.95 & 15.83 & 0.017 & 0.155 & 0.050 \\
\hline \multirow[t]{2}{*}{ W107 $43.782^{\prime}$} & & 64.22 & 1021 & 1.92 & 1.76 & 14.49 & 0.031 & 0.142 & 0.048 \\
\hline & & & 1115 & & & & & & \\
\hline
\end{tabular}

$\begin{array}{lllllllll}\text { HW16-08-01 } & 39.14 & 77.90 & 1.95 & 1.60 & 14.60 & 0.029 & 0.143 & 0.048 \\ \text { paleosol } 1 & & & & & \end{array}$
paleosol 1 N44 01.126' W107 $43.795^{\prime}$

\begin{tabular}{|c|c|c|c|c|c|c|c|c|c|}
\hline HW16-08-01 & 38.3 & 78.92 & 1072 & 1.96 & 1.52 & 14.78 & 0.027 & 0.145 & 0.049 \\
\hline \multicolumn{10}{|l|}{ paleosol 2} \\
\hline HW16-08-01 & 34.92 & 69.88 & 1150 & 2.03 & 0.92 & 15.80 & 0.0164 & 0.155 & 0.050 \\
\hline \multirow[t]{2}{*}{ paleosol 3} & & 66.00 & 1062 & 2.20 & 1.28 & 15.32 & 0.0228 & 0.150 & 0.055 \\
\hline & & & 1106 & & & & & & \\
\hline HW16-08-01 & 33.65 & 69.39 & 1139 & 2.08 & 0.95 & 15.88 & 0.017 & 0.1557 & 0.052 \\
\hline \multirow[t]{4}{*}{ paleosol 4} & & 70.69 & 1168 & 1.97 & 1.00 & 16.43 & 0.018 & 0.1611 & 0.049 \\
\hline & & 70.65 & 1167 & 1.95 & 0.85 & 15.59 & 0.015 & 0.1529 & 0.048 \\
\hline & & 70.99 & 1175 & 1.97 & 0.82 & 15.83 & 0.015 & 0.1553 & 0.049 \\
\hline & & & 1162 & & & & & & \\
\hline HW16-08-17 & 22.03 & 68.41 & 1116 & 2.42 & 1.14 & 17.74 & 0.020 & 0.174 & 0.060 \\
\hline $\mathrm{N} 44^{\circ} 01.561^{\prime}$ & & 69.91 & 1151 & 2.40 & 0.85 & 17.70 & 0.015 & 0.174 & 0.060 \\
\hline \multirow[t]{3}{*}{ W107 $43.640^{\prime}$} & & 71.95 & 1197 & 2.21 & 0.71 & 17.68 & 0.013 & 0.173 & 0.055 \\
\hline & & 71.05 & 1176 & 2.20 & 0.86 & 17.50 & 0.015 & 0.172 & 0.055 \\
\hline & & 70.88 & 1172 & 2.21 & 0.92 & 17.68 & 0.016 & 0.173 & 0.055 \\
\hline
\end{tabular}




\begin{tabular}{|c|c|c|c|c|c|c|c|c|c|}
\hline & & & 1162 & & & & & & \\
\hline HW16-08-19 & 19.39 & 71.68 & 1191 & 1.91 & 0.7 & 15.45 & 0.012 & 0.152 & 0.047 \\
\hline $\mathrm{N}^{\prime \circ}{ }^{\circ} 01.574^{\prime}$ & & 71.29 & 1182 & 1.88 & 0.68 & 14.88 & 0.012 & 0.146 & 0.047 \\
\hline \multirow[t]{4}{*}{ W107 $43.665^{\prime}$} & & 71.25 & 1181 & 1.86 & 0.72 & 14.93 & 0.013 & 0.146 & 0.046 \\
\hline & & 70.20 & 1157 & 1.97 & 0.82 & 15.26 & 0.015 & 0.150 & 0.049 \\
\hline & & 69.87 & 1149 & 1.86 & 0.75 & 14.08 & 0.013 & 0.138 & 0.046 \\
\hline & & & 1172 & & & & & & \\
\hline HW16-08-19 lower & 14.87 & 61.82 & 967 & 2.15 & 2.15 & 15.13 & 0.038 & 0.148 & 0.053 \\
\hline HW16-08-20 & 12.77 & 75.81 & 1284 & 1.68 & 0.57 & 16.58 & 0.010 & 0.163 & 0.042 \\
\hline upper paleosol & & 74.98 & 1265 & 1.78 & 0.54 & 16.44 & 0.010 & 0.161 & 0.044 \\
\hline $\mathrm{N} 44^{\circ} 01.581^{\prime}$ & & 73.53 & 1233 & 1.84 & 0.64 & 16.16 & 0.011 & 0.159 & 0.046 \\
\hline \multirow[t]{3}{*}{$W 107^{\circ} 43.682^{\prime}$} & & 71.99 & 1198 & 1.78 & 0.95 & 16.03 & 0.017 & 0.157 & 0.044 \\
\hline & & 73.04 & 1221 & 1.67 & 0.85 & 15.63 & 0.015 & 0.153 & 0.041 \\
\hline & & & 1240 & & & & & & \\
\hline HW16-08-20 & 11.05 & 73.26 & 1226 & 1.73 & 0.81 & 16.06 & 0.015 & 0.158 & 0.043 \\
\hline \multirow[t]{3}{*}{ lower paleosol } & & 74.57 & 1256 & 1.75 & 0.66 & 16.54 & 0.012 & 0.162 & 0.044 \\
\hline & & 75.05 & 1267 & 1.74 & 0.62 & 16.65 & 0.011 & 0.163 & 0.043 \\
\hline & & & 1250 & & & & & & \\
\hline
\end{tabular}


Table S2. Paleosol thickness and estimated time represented in CAB 10 composite section.

\begin{tabular}{lcc} 
Paleosol & $\begin{array}{c}\text { B horizon } \\
\text { Thickness }(\mathbf{m})\end{array}$ & $\begin{array}{c}\text { Time } \\
\text { (years) }\end{array}$ \\
\hline BR 2 & 1.15 & 19,942 \\
BR 1 & 1.03 & 17,861 \\
BR 0 & 1.28 & 22,196 \\
SLIRB 4 & 0.42 & 7,283 \\
SLIRB 3 & 0.36 & 6,243 \\
SLIRB 2 & 0.23 & 3,988 \\
SLIRB 1 & 0.36 & 6,243 \\
Purple 2 & 0.87 & 15,087 \\
Purple 1 & 0.23 & 3,988 \\
LIRB2 & 1.33 & 23,064 \\
LIRB1 & 1.39 & 24,104 \\
\hline Totals & 8.65 & 150,000 \\
\hline Total soil thickness $=8.65 \mathrm{~m}$ & $1 \mathrm{~m}=17,341 \mathrm{yr}$ \\
Total avulsion thick $=25.1 \mathrm{~m}$ & $1 \mathrm{~m}=1000 \mathrm{yr}$
\end{tabular}


Table S3. Age model based on paleosol development in CAB10 composite section.

\begin{tabular}{lccccccc} 
Paleosol & Strat & Strat & thickness & soil & avulsion & Strat Level & Cumul \\
& Base & Top & $(\mathrm{m})$ & time & time & $(\mathbf{m})$ & Time (yrs) \\
\hline BR6 top & 54.3 & 54.88 & 0.58 & 10058 & 0 & 54.88 & 246980 \\
Avulsion/Base BR 6 & 53.4 & 54.3 & 0.9 & 0 & 900 & 54.30 & 236922 \\
BR5 top & 53.19 & 53.4 & 0.21 & 3642 & 0 & 53.4 & 236022 \\
Avulsion/Base BR 5 & 52.38 & 53.19 & 0.81 & 0 & 810 & 53.19 & 232380 \\
BR4 top & 51.63 & 52.38 & 0.75 & 13006 & 0 & 52.38 & 231570 \\
Avulsion/Base BR 4 & 50.5 & 51.63 & 1.13 & 0 & 1130 & 51.63 & 218564 \\
BR3 top & 48.05 & 50.5 & 2.45 & 42485 & 0 & 50.5 & 217434 \\
Avulsion/Base BR 3 & 44.75 & 48.05 & 3.3 & 0 & 3300 & 48.05 & 174949 \\
BR2 top & 43.6 & 44.75 & 1.15 & 19942 & 0 & 44.75 & 171649 \\
Avulsion/Base BR 2 & 42.53 & 43.6 & 1.07 & 0 & 1070 & 43.60 & 151707 \\
BR1 top & 41.5 & 42.53 & 1.03 & 17861 & 0 & 42.53 & 150637 \\
Avulsion/Base BR 1 & 41.14 & 41.5 & 0.36 & 0 & 360 & 41.50 & 132776 \\
BR0 top & 39.86 & 41.14 & 1.28 & 22196 & 0 & 41.14 & 132416 \\
Avulsion/Base BR 0 & 24.65 & 39.86 & 15.21 & 0 & 15210 & 39.86 & 110220 \\
SLIRB 4 top & 24.23 & 24.65 & 0.42 & 7283 & 0 & 24.65 & 95010 \\
Avulsion/Base SLIRB4 & 23.29 & 24.23 & 0.94 & 0 & 940 & 24.23 & 87727 \\
SLIRB 3 top & 22.93 & 23.29 & 0.36 & 6243 & 0 & 23.29 & 86787 \\
Avulsion/Base SLIRB3 & 22.01 & 22.93 & 0.92 & 0 & 920 & 22.93 & 80544 \\
SLIRB 2 top & 21.78 & 22.01 & 0.23 & 3988 & 0 & 22.01 & 79624 \\
Avulsion/Base SLIRB2 & 21.58 & 21.78 & 0.2 & 0 & 200 & 21.78 & 75636 \\
SLIRB 1 top & 21.22 & 21.58 & 0.36 & 6243 & 0 & 21.58 & 75436 \\
Avulsion/Base SLIRB1 & 19.74 & 21.22 & 1.48 & 0 & 1480 & 21.22 & 69193 \\
Purple 2 top & 18.87 & 19.74 & 0.87 & 15087 & 0 & 19.74 & 67713 \\
Avulsion/Base LIRB4 & 18.41 & 18.87 & 0.46 & 0 & 460 & 18.87 & 52626 \\
Purple 1 top & 18.18 & 18.41 & 0.23 & 3988 & 0 & 18.41 & 52166 \\
Avulsion/Base LIRB3 & 17.89 & 18.18 & 0.29 & 0 & 290 & 18.18 & 48178 \\
LIRB2 top & 16.56 & 17.89 & 1.33 & 23064 & 0 & 17.65 & 47888 \\
Avulsion/Base LIRB2 & 15.84 & 16.56 & 0.72 & 0 & 720 & 16.56 & 24824 \\
LIRB 1 top & 14.45 & 15.84 & 1.39 & 24104 & 0 & 15.84 & 24104 \\
LIRB 1 base & & & & & & 14.45 & 0 \\
\hline & & & & & & &
\end{tabular}


Table S4. Regression statistics for natural log of Sifrhippus M/1 area on Coryphodon $\delta^{18} \mathrm{O}_{\mathrm{E}}$ values. P-values significant with $95 \%$ confidence are shown in bold.

\begin{tabular}{|c|c|c|c|c|c|c|c|c|}
\hline \multicolumn{9}{|c|}{6 Meter Bins } \\
\hline Start & $\mathbf{n}$ & & & & & & SW & sw \\
\hline Level & Bins & $\mathbf{R}^{2}$ & $P$ & DW & DW L & DW U & $\delta^{18} O$ & M/1 \\
\hline 8 & 6 & 0.77 & 0.022 & 2.43 & 0.61 & 1.40 & 0.59 & 0.92 \\
\hline 9 & 9 & 0.60 & 0.014 & 1.90 & 0.82 & 1.32 & 0.82 & 0.56 \\
\hline 10 & 9 & 0.71 & 0.005 & 1.61 & 0.82 & 1.32 & 0.67 & 0.25 \\
\hline 11 & 9 & 0.67 & 0.007 & 1.82 & 0.82 & 1.32 & 0.52 & 0.19 \\
\hline 12 & 9 & 0.67 & 0.007 & 1.63 & 0.82 & 1.32 & 0.72 & 0.41 \\
\hline 13 & 8 & 0.75 & 0.005 & 1.26 & 0.76 & 1.33 & 0.52 & 0.54 \\
\hline means & 8.3 & 0.70 & 0.010 & & & & & \\
\hline \multicolumn{9}{|c|}{5 Meter Bins } \\
\hline 8 & 9 & 0.74 & 0.003 & 1.36 & 0.82 & 1.32 & 1.00 & 0.52 \\
\hline 9 & 8 & 0.51 & 0.046 & 2.03 & 0.76 & 1.33 & 0.95 & 0.72 \\
\hline 10 & 9 & 0.53 & 0.027 & 1.76 & 0.82 & 1.32 & 0.90 & 0.46 \\
\hline 11 & 8 & 0.69 & 0.010 & 1.47 & 0.76 & 1.33 & 0.25 & 0.31 \\
\hline 12 & 8 & 0.77 & 0.004 & 2.05 & 0.76 & 1.33 & 0.80 & 0.28 \\
\hline means & 8.4 & 0.65 & 0.018 & & & & & \\
\hline \multicolumn{9}{|c|}{4 Meter Bins } \\
\hline 9 & 8 & 0.59 & 0.026 & 2.40 & 0.76 & 1.33 & 0.46 & 0.41 \\
\hline 10 & 9 & 0.60 & 0.015 & 1.24 & 0.82 & 1.32 & 0.27 & 0.61 \\
\hline 11 & 10 & 0.58 & 0.011 & 1.09 & 0.88 & 1.32 & 0.68 & 0.56 \\
\hline 12 & 9 & 0.72 & 0.028 & 2.51 & 0.82 & 1.32 & 0.38 & 0.70 \\
\hline means & 9.0 & 0.62 & 0.020 & & & & & \\
\hline
\end{tabular}

Abbreviations: $\mathrm{n}$, number of bins; $\mathrm{R}^{2}$, coefficient of determination; $p$, probability of random correlation; DWL, DW, Durbin Watson statistic; Durbin-Watson lower critical value; DWL, Durbin-Watson upper critical value; SW, Shapiro-Wilk statistic. 
Table S5. Regression statistics for natural log of Sifrhippus M/1 area on Sifrhippus $\delta^{18} \mathrm{O}_{\mathrm{E}}$ values. $\mathrm{P}$-values significant with $95 \%$ confidence shown in bold.

\begin{tabular}{|c|c|c|c|c|c|c|c|c|}
\hline \multicolumn{9}{|c|}{6 Meter Bins } \\
\hline Start & $n$ & & & & & & & SW \\
\hline Level & Bins & $\mathbf{R}^{2}$ & $p$ & DW & DW L & DW U & $\delta^{18} 0$ & $M / 1$ \\
\hline 9 & 9 & 0.41 & 0.064 & 1.33 & 0.82 & 1.32 & 0.04 & 0.34 \\
\hline 10 & 10 & 0.38 & 0.057 & 1.16 & 0.88 & 1.32 & 0.14 & 0.15 \\
\hline 11 & 10 & 0.40 & 0.049 & 1.21 & 0.88 & 1.32 & 0.10 & 0.09 \\
\hline 12 & 9 & 0.67 & 0.007 & 1.35 & 0.82 & 1.32 & 0.38 & 0.18 \\
\hline 13 & 8 & 0.48 & 0.056 & 1.38 & 0.76 & 1.33 & 0.21 & 0.26 \\
\hline 14 & 7 & 0.62 & 0.035 & 1.94 & 0.70 & 1.36 & 0.11 & 0.71 \\
\hline means & 8.8 & 0.494 & 0.045 & & & & & \\
\hline \multicolumn{9}{|c|}{5 Meter Bins } \\
\hline 10 & 11 & 0.39 & 0.057 & 1.51 & 0.93 & 1.32 & 0.23 & 0.04 \\
\hline 11 & 10 & 0.45 & 0.033 & 1.10 & 0.88 & 1.32 & 0.21 & 0.16 \\
\hline 12 & 9 & 0.38 & 0.075 & 1.21 & 0.82 & 1.32 & 0.04 & 0.04 \\
\hline 13 & 10 & 0.69 & 0.003 & 1.59 & 0.88 & 1.32 & 0.29 & 0.29 \\
\hline 14 & 9 & 0.35 & 0.096 & 1.53 & 0.82 & 1.32 & 0.56 & 0.33 \\
\hline means & 9.8 & 0.453 & 0.053 & & & & & \\
\hline \multicolumn{9}{|c|}{4 Meter Bins } \\
\hline 11 & 12 & 0.42 & 0.022 & 1.11 & 0.97 & 1.33 & 0.04 & 0.45 \\
\hline 12 & 11 & 0.67 & 0.002 & 1.05 & 0.93 & 1.32 & 0.87 & 0.81 \\
\hline 13 & 10 & 0.33 & 0.084 & 1.42 & 0.88 & 1.32 & 0.44 & 0.06 \\
\hline 14 & 11 & 0.38 & 0.042 & 1.08 & 0.93 & 1.32 & 0.16 & 0.17 \\
\hline means & 11.0 & 0.450 & 0.038 & & & & & \\
\hline
\end{tabular}

Abbreviations as in Table S3 
Table S6. Regression statistics for natural log of faunal (Ectocion, Copecion, Sifrhippus) $\delta^{13} \mathrm{C}_{\mathrm{E}}$ values on Coryphodon $\delta^{18} \mathrm{O}$ values. P-values significant with $95 \%$ confidence shown in bold.

\begin{tabular}{|c|c|c|c|c|c|c|c|c|}
\hline \multicolumn{9}{|c|}{6 Meter Bins } \\
\hline Start & $\underset{\text { Rins }}{\mathbf{n}}$ & R2 & $n$ & DW & DW & DW & $\begin{array}{c}\text { SW } \\
\delta 180\end{array}$ & SW \\
\hline-4 & 8 & 0.78 & 0.004 & 1.80 & 0.76 & 1.33 & 0.76 & 0.07 \\
\hline-3 & 9 & 0.51 & 0.031 & 2.08 & 0.82 & 1.32 & 0.72 & 0.10 \\
\hline-2 & 10 & 0.39 & 0.054 & 2.08 & 0.88 & 1.32 & 0.62 & 0.18 \\
\hline-1 & 10 & 0.46 & 0.031 & 2.20 & 0.88 & 1.32 & 0.38 & 0.13 \\
\hline 0 & 9 & 0.48 & 0.038 & 2.31 & 0.82 & 1.32 & 0.62 & 0.20 \\
\hline 1 & 8 & 0.56 & 0.033 & 2.26 & 0.76 & 1.33 & 0.69 & 0.14 \\
\hline means & 9.0 & 0.529 & 0.032 & & & & & \\
\hline \multicolumn{9}{|c|}{5 Meter Bins } \\
\hline 1 & 10 & 0.60 & 0.008 & 2.51 & 0.88 & 1.32 & 0.27 & 0.37 \\
\hline 0 & 10 & 0.47 & 0.028 & 2.24 & 0.88 & 1.32 & 0.80 & 0.14 \\
\hline-1 & 10 & 0.45 & 0.035 & 2.10 & 0.88 & 1.32 & 0.79 & 0.10 \\
\hline-2 & 9 & 0.55 & 0.022 & 1.97 & 0.82 & 1.32 & 0.87 & 0.04 \\
\hline-3 & 10 & 0.46 & 0.032 & 1.57 & 0.88 & 1.32 & 0.82 & 0.04 \\
\hline means & 9.8 & 0.506 & 0.025 & & & & & \\
\hline \multicolumn{9}{|c|}{4 Meter Bins } \\
\hline-2 & 11 & 0.47 & 0.020 & 1.79 & 0.93 & 1.32 & 0.25 & 0.59 \\
\hline-1 & 11 & 0.44 & 0.026 & 1.93 & 0.93 & 1.32 & 0.49 & 0.40 \\
\hline 0 & 11 & 0.51 & 0.014 & 2.15 & 0.93 & 1.32 & 0.87 & 0.04 \\
\hline 1 & 10 & 0.46 & 0.031 & 1.93 & 0.88 & 1.32 & 0.92 & 0.05 \\
\hline means & 10.8 & 0.470 & 0.023 & & & & & \\
\hline
\end{tabular}

Abbreviations as in Table S3 
Table S7. List of PETM mammal species showing average estimated change in body mass from pre-PETM congeners (pre-CIE,

Copecion biozone, Cf-3) to PETM (Meniscotherium priscum and “Hyracotherium” sandrae biozones), and PETM to post-PETM congeners (post-CIE, Cardiolophus radinskyi biozone, Wa-1) intervals. All estimates are based on first lower molar area, except for Palaeanodon, which is based on humeral radial measurements. Data for Sifrhippus from this study. See SOM text for caveats regarding some taxa.

\begin{tabular}{|c|c|c|c|c|c|c|c|c|}
\hline Order & Family & PETM species & $\begin{array}{c}\% \\
\text { change } \\
\text { Pre- } \\
\text { PETM } \\
\text { to } \\
\text { PETM }\end{array}$ & $\begin{array}{c}\% \\
\text { change } \\
\text { PETM } \\
\text { to } \\
\text { Post- } \\
\text { PETM }\end{array}$ & Diet & $\begin{array}{l}\text { Locomotor } \\
\text { Behavior }\end{array}$ & $\begin{array}{c}\text { Range } \\
\text { Through? }\end{array}$ & Sources \\
\hline Multituberculata & Ptilodontidae & Ectypodus tardus & 0 & 0 & Omnivore & A & $\mathrm{R}$ & $(1-4)$ \\
\hline Multituberculata & Ptilodontidae & Parectypodus lunatus & - & 0 & Omnivore & A & FA & $(1,3,4)$ \\
\hline Didelphimorphia & Didelphidae & Mimoperadectes labrus & 0 & 0 & Omnivore & $S / A$ & $\mathrm{R}$ & $(1-5)$ \\
\hline Didelphimorphia & Didelphidae & Peradectes protinnominatus & 0 & 0 & Omnivore & $S / A$ & $\mathrm{R}$ & $(1,3-5)$ \\
\hline Didelphimorphia & Herpetotheriidae & Peratherium innominatum & 0 & 0 & Omnivore & $S / A$ & $\mathrm{R}$ & $(1,3,4)$ \\
\hline Rodentia & Ischyromyidae & Acritoparamys atwateri & 0 & 0 & Herbivore & $\mathrm{s}$ & $\mathrm{R}$ & $(1-4)$ \\
\hline Rodentia & Ischyromyidae & Microparamys hunterae & - & 0 & Herbivore & $\mathrm{S}$ & FA & $(1,6)$ \\
\hline Rodentia & Ischyromyidae & Paramys annectens & 0 & 0 & Herbivore & $\mathrm{s}$ & $\mathrm{R}$ & $(1,6)$ \\
\hline Rodentia & Ischyromyidae & Paramys copei & 0 & 0 & Herbivore & S & $\mathrm{R}$ & $(1,3,4)$ \\
\hline Rodentia & Ischyromyidae & Paramys taurus & 0 & 0 & Herbivore & S & $\mathrm{R}$ & $(1,2,4)$ \\
\hline Rodentia & Ischyromyidae & Reithroparamys sp. & - & 0 & Herbivore & S? & FA? & $(1,6)$ \\
\hline Cimolesta & Apatemyidae & Apatemys sp. & 0 & 0 & Insectivore & A & $\mathrm{R}$ & $(1,3,5)$ \\
\hline Taeniodonta & Stylinodontidae & Ectoganus bighornensis & - & - & Herbivore & $\mathrm{T}$ & $R$ & $(1,2)$ \\
\hline Tillodontia & Esthonychidae & Azygonyx gunnelli & -40 & - & Herbivore & $\mathrm{T} / \mathrm{S}$ & $\mathrm{R}$ & $(1,2,4,7)$ \\
\hline Tillodontia & Esthonychidae & Esthonyx spatularius & - & 0 & Herbivore & $\mathrm{T}$ & FA & $(1,2)$ \\
\hline Pantodonta & Coryphodontidae & Coryphodon sp. & - & 0 & Herbivore & $\mathrm{T}$ & $\mathrm{R}$ & $(1-5)$ \\
\hline Palaeanodonta & Metacheiromyidae & Palaeanodon nievelti & -58 & 0 & Insectivore & $\mathrm{T}$ & $R$ & $(2,8,9)$ \\
\hline Creodonta & Hyaenodontidae & Acarictis ryani & - & 0 & Carnivore & $\mathrm{T}$ & FA & $(1-3,10)$ \\
\hline Creodonta & Hyaenodontidae & Arfia junnei & - & 82 & Carnivore & $\mathrm{T}$ & FA & (1) \\
\hline Creodonta & Hyaenodontidae & Prolimnocyon eerius & - & 35 & Carnivore & $\mathrm{s}$ & FA & $(1,2)$ \\
\hline
\end{tabular}




\begin{tabular}{|c|c|c|c|c|c|c|c|c|}
\hline Creodonta & Hyaenodontidae & Prototomus deimos & - & 29 & Carnivore & S/A? & FA & $(2,10)$ \\
\hline Creodonta & Oxyaenidae & Dipsalidictis platypus & 0 & 0 & $\begin{array}{l}\text { Carnivore } \\
\text { Carnivore/ }\end{array}$ & $\mathrm{T}$ & $\mathrm{R}$ & $(1,2,11)$ \\
\hline Creodonta & Oxyaenidae & Palaeonictis wingi & -65 & 65 & Omnivore & $\mathrm{T}$ & $\mathrm{R}$ & $(1,12)$ \\
\hline Carnivoramorpha & Miacidae & Miacis deutschi & - & 0 & Carnivore & $S / A ?$ & FA & $(1,3,13)$ \\
\hline Carnivoramorpha & Miacidae & Miacis rosei & - & - & Carnivore & S/A? & FA & $(1,14)$ \\
\hline Carnivoramorpha & Miacidae & Miacis winkleri & - & 0 & $\begin{array}{l}\text { Carnivore } \\
\text { Carnivore/ }\end{array}$ & $S / A ?$ & FA & $(1,2,13)$ \\
\hline Carnivoramorpha & Miacidae & Uintacyon gingerichi & -49 & 94 & Omnivore & $S / A$ & $\mathrm{R}$ & $(1,12,14)$ \\
\hline Carnivoramorpha & Miacidae & Vassacyon bowni & - & 80 & Carnivore & $S / A$ & $\mathrm{FA}$ & $(1,14)$ \\
\hline Carnivoramorpha & Viverravidae & Didymictis leptomylus & 0 & 0 & Carnivore & $\mathrm{T}$ & $\mathrm{R}$ & $(1,2,4)$ \\
\hline Carnivoramorpha & Viverravidae & Viverravus politus & 0 & 0 & Carnivore & $\mathrm{T}$ & $\mathrm{R}$ & $(1,3,15)$ \\
\hline Erinaceomorpha & Amphilemuridae & Macrocranion junnei & - & - & Insectivore & $\mathrm{T} / \mathrm{Sa}$ & $\mathrm{FA}$ & $(1,3,4,16)$ \\
\hline Soricomorpha & Nyctitheriidae & Plagioctenodon savagei & - & 0 & Insectivore & S? & FA & $(1,3)$ \\
\hline Primates & Adapidae & Cantius torresi & - & 14 & $\begin{array}{l}\text { Frugivore } \\
\text { Omnivore/ }\end{array}$ & $A$ & $\mathrm{FA}$ & $(1,2)$ \\
\hline Primates & Micromomyidae & Tinimomys graybulliensis & 0 & 0 & $\begin{array}{c}\text { Insectivore? } \\
\text { Omnivore/ }\end{array}$ & $A ?$ & $\mathrm{R}$ & $(1,3,5,17)$ \\
\hline Primates & Microsyopidae & Arctodontomys wilsoni & - & 25 & $\begin{array}{c}\text { Insectivore? } \\
\text { Omnivore/ }\end{array}$ & $A ?$ & $\mathrm{FA}$ & $(1,2)$ \\
\hline Primates & Microsyopidae & Niptomomys doreenae & 0 & 0 & $\begin{array}{c}\text { Insectivore? } \\
\text { Omnivore/ }\end{array}$ & $A ?$ & $\mathrm{R}$ & $(1,4)$ \\
\hline Primates & Microsyopidae & Niptomomys favorum & - & - & $\begin{array}{c}\text { Insectivore? } \\
\text { Omnivore/ }\end{array}$ & $A ?$ & $\mathrm{R}$ & $(1,3,6)$ \\
\hline Primates & Omomyidae & Teilhardina brandti & - & 0 & $\begin{array}{c}\text { Insectivore } \\
\text { Frugivore/ } \\
\text { Exudate- }\end{array}$ & $A$ & $\mathrm{FA}$ & $(1,18)$ \\
\hline Primates & Paromomyidae & Phenacolemur praecox & 0 & 0 & feeder & A & $\mathrm{R}$ & $(1,2,4)$ \\
\hline Condylarthra & Apheliscidae & Haplomylus zalmouti & -71 & 97 & Herbivore & $\mathrm{C} / \mathrm{Sa}$ & $\mathrm{R}$ & $(1,6)$ \\
\hline Condylarthra & Arctocyonidae & Chriacus badgleyi & -55 & 62 & Omnivore & $S / A$ & $\mathrm{R}$ & $(1,2)$ \\
\hline Condylarthra & Arctocyonidae & Princetonia yalensis & 0 & - & Omnivore? & $\mathrm{T} / \mathrm{S}$ & $\mathrm{R}$ & $(1-3)$ \\
\hline Condylarthra & Arctocyonidae & Thryptacodon barae & -39 & 35 & Omnivore & S/A? & $\mathrm{R}$ & $(1,2,5)$ \\
\hline Condylarthra & Hyopsodontidae & Hyopsodus loomisi & -46 & 16 & Herbivore & $\mathrm{T} ?$ & $\mathrm{R}$ & $(1,2,19)$ \\
\hline Condylarthra & Phenacodontidae & Copecion davisi & -46 & 85 & Herbivore & $\mathrm{T}$ & $\mathrm{R}$ & $(1,2)$ \\
\hline Condylarthra & Phenacodontidae & Ectocion parvus & -48 & 91 & Herbivore & $\mathrm{T}$ & $\mathrm{R}$ & $(1,2)$ \\
\hline Condylarthra & Phenacodontidae & Phenacodus intermedius & 0 & 0 & Herbivore & $\mathrm{T}$ & $\mathrm{R}$ & $(1-3,20)$ \\
\hline Condylarthra & Phenacodontidae & Phenacodus vortmani & 0 & 0 & Herbivore & $\mathrm{T}$ & $\mathrm{R}$ & $(1-3,6,20)$ \\
\hline Mesonychia & Mesonychidae & Dissacus praenuntius & 0 & 0 & Carnivore & $\mathrm{T} / \mathrm{C}$ & $\mathrm{R}$ & $(1-3)$ \\
\hline Mesonychia & Mesonychidae & Pachyaena ossifraga & - & 0 & Carnivore & $\mathrm{T} / \mathrm{C}$ & $\mathrm{FA}$ & $(1,4)$ \\
\hline
\end{tabular}




\begin{tabular}{|c|c|c|c|c|c|c|c|c|}
\hline Artiodactyla & Dichobunidae & Diacodexis ilicis & - & $\begin{array}{l}10 \\
76\end{array}$ & $\begin{array}{l}\text { Herbivore } \\
\text { Herbivore }\end{array}$ & $\begin{array}{l}\mathrm{T} / \mathrm{C} \\
\mathrm{T} / \mathrm{C}\end{array}$ & $\begin{array}{l}F A \\
F A\end{array}$ & $(1,2,19)$ \\
\hline \multirow{2}{*}{\multicolumn{3}{|c|}{$\begin{array}{l}\text { Total species (for which body size approximations can be made) } \\
\text { Total genera (for which body size approximations can be made) }\end{array}$}} & 29 & 45 & & & & \\
\hline & & & 26 & 40 & & & & \\
\hline \multicolumn{3}{|c|}{ Paleocene genera with smaller PETM congeners } & 10 & & & & & \\
\hline \multicolumn{3}{|c|}{ PETM genera with smaller post-PETM congeners } & & 16 & & & & \\
\hline \multirow{2}{*}{\multicolumn{3}{|c|}{ Percent Paleocene genera with smaller PETM congeners }} & 38 & & & & & \\
\hline & & & & 40 & & & & \\
\hline
\end{tabular}

- , species is either not present or is too poorly represented for estimate.

Locomotor behavior (Lcmtr Bhvr) Column: A, Arboreal; C, Cursorial; S, Scansorial; Sa, Saltatorial; T, Terrestrial.

Range Through? Column: Range through: $R$, range through; FA, first appearance. 
Table S8. First molar (M/1) measurements for the equid Sifrhippus used to estimate body size changes.

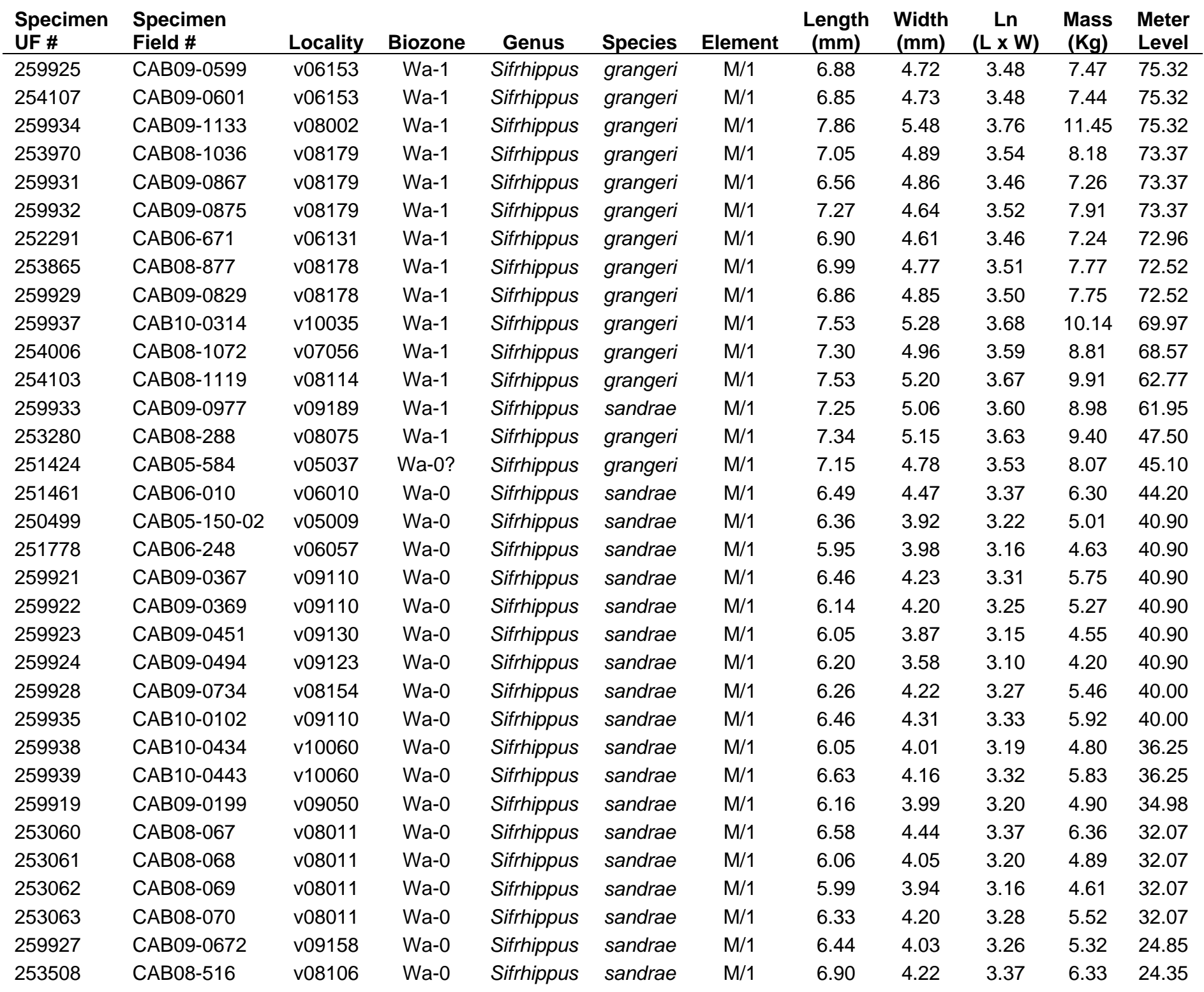




\begin{tabular}{|c|c|c|c|c|c|c|c|c|c|c|c|}
\hline 250055 & CAB04-512 & v04148 & Wa-0 & Sifrhippus & sandrae & $\mathrm{M} / 1$ & 6.84 & 4.32 & 3.39 & 6.47 & 23.66 \\
\hline 259936 & CAB10-0259 & v05108 & Wa-0 & Sifrhippus & sandrae & $\mathrm{M} / 1$ & 6.25 & 4.17 & 3.26 & 5.35 & 23.11 \\
\hline 249832 & CAB04-392 & v04105 & Wa-0 & Sifrhippus & sandrae & $\mathrm{M} / 1$ & 6.70 & 4.33 & 3.37 & 6.30 & 20.75 \\
\hline 259920 & CAB09-0247 & v09063 & Wa-0 & Sifrhippus & sandrae & $\mathrm{M} / 1$ & 6.69 & 4.26 & 3.35 & 6.13 & 17.65 \\
\hline 254902 & CAB09-0785 & v09174 & Wa-0 & Sifrhippus & sandrae & $\mathrm{M} / 1$ & 6.95 & 4.53 & 3.45 & 7.13 & 17.65 \\
\hline 250233 & CAB05-030-31 & v05006 & Wa-0 & Sifrhippus & sandrae & $\mathrm{M} / 1$ & 6.62 & 4.84 & 3.47 & 7.32 & 17.02 \\
\hline 250234 & CAB05-030-32 & v05006 & Wa-0 & Sifrhippus & sandrae & $\mathrm{M} / 1$ & 6.60 & 4.48 & 3.39 & 6.48 & 17.02 \\
\hline 251570 & CAB06-079 & v05006 & Wa-0 & Sifrhippus & sandrae & $\mathrm{M} / 1$ & 7.07 & 4.74 & 3.51 & 7.83 & 17.02 \\
\hline 251517 & CAB06-054-02 & v06014 & Wa-0 & Sifrhippus & sandrae & $\mathrm{M} / 1$ & 6.83 & 4.57 & 3.44 & 7.03 & 14.45 \\
\hline
\end{tabular}


Table S9. Fossil teeth sampled for stable isotopes.

\begin{tabular}{|c|c|c|c|c|c|c|c|c|c|c|c|}
\hline $\begin{array}{l}\text { USNM } \\
\#\end{array}$ & UF \# & $\begin{array}{l}\text { Sample } \\
\text { \# }\end{array}$ & Field \# & $\begin{array}{l}\text { Locality } \\
\#\end{array}$ & Biozone & Genus & Species & $\delta^{13} \mathrm{C}$ & $\delta^{18} 0$ & $\begin{array}{l}\text { Meter } \\
\text { Level }\end{array}$ & $\begin{array}{l}\text { Element } \\
\text { Sampled }\end{array}$ \\
\hline & 250459 & SB1-01 & CAB05-587 & v05108 & Wa-0 & Ectocion & parvus & -14.5 & 22.7 & 23.11 & R M3/ \\
\hline & 250759 & SB1-02 & CAB05-264 & v05067 & Wa-0 & Ectocion & parvus & -13.9 & 24.9 & 17.65 & $\mathrm{~L} \mathrm{M} / 1$ \\
\hline & 249223 & SB1-04 & CAB04-022 & v04005 & Cf-3 & Ectocion & osbornianus & -7.4 & 23.2 & 2.29 & $\mathrm{~L} \mathrm{M} / 2$ \\
\hline & 249291 & SB1-09 & CAB04-087 & v04017 & Cf-3 & Ectocion & osbornianus & -10.4 & 22.3 & 2.14 & L P4/ \\
\hline & 249297 & SB1-10 & CAB04-093 & v04017 & Cf-3 & Ectocion & osbornianus & -11.6 & 20.7 & 2.14 & $\mathrm{R} M / 3$ \\
\hline & 249331 & SB1-11 & CAB04-121 & v04027 & Cf-3 & Ectocion & osbornianus & -11.4 & 21.4 & 2.82 & $\mathrm{~L} \mathrm{M} / 1$ \\
\hline & 249358 & SB1-13 & CAB04-142-A & v04037 & Cf-3 & Copecion & brachypternus & -9.8 & 22.2 & 2.38 & R M1/ \\
\hline & 249358 & SB1-14 & CAB04-142-B & v04037 & Cf-3 & Copecion & brachypternus & -10.7 & 22.1 & 2.38 & $\mathrm{R} \mathrm{M} / 1$ \\
\hline & 249365 & SB1-15 & CAB04-148 & v04040 & Cf-3 & Ectocion & osbornianus & -12.0 & 21.2 & 1.00 & $\mathrm{R} M / 3$ \\
\hline & 249376 & SB1-16 & CAB04-155 & v04041 & Cf-3 & $\begin{array}{l}\text { Ectocion or } \\
\text { Copecion }\end{array}$ & $\begin{array}{l}\text { osbornianus or } \\
\text { brachypternus }\end{array}$ & -11.9 & 20.4 & 2.79 & $M x /$ frag \\
\hline & 249379 & SB1-17 & CAB04-158-1 & v04042 & Cf-3 & $\begin{array}{l}\text { Ectocion or } \\
\text { Copecion }\end{array}$ & $\begin{array}{l}\text { osbornianus or } \\
\text { brachypternus }\end{array}$ & -10.2 & 21.8 & 2.79 & L P4/ \\
\hline & 249661 & SB1-20 & 3 & v04105 & Wa-0 & Ectocion & parvus & -13.7 & 23.2 & 20.75 & $\mathrm{R} M 3 /$ \\
\hline & 249811 & SB1-21 & CAB04-371 & v04105 & Wa-0 & Copecion & davisi & -14.1 & 23.2 & 20.75 & $\mathrm{R} \mathrm{M} / 1$ or $\mathrm{M} / 2$ \\
\hline & 249816 & SB1-22 & CAB04-376 & v04105 & Wa-0 & Ectocion & parvus & -14.3 & 25.0 & 20.75 & R M2/ \\
\hline & 249817 & SB1-23 & CAB04-377 & v04105 & Wa-0 & Copecion & davisi & -14.1 & 23.8 & 20.75 & L M2/ \\
\hline & 249819 & SB1-24 & CAB04-379 & v04105 & Wa-0 & Copecion & davisi & -14.8 & 23.6 & 20.75 & R M1/ \\
\hline & 249822 & SB1-25 & CAB04-382 & v04105 & Wa-0 & Ectocion & parvus & -14.8 & 21.0 & 20.75 & $\mathrm{~L} \mathrm{M} / 1$ \\
\hline & 249824 & SB1-26 & CAB04-384 & v04105 & Wa-0 & Ectocion & parvus & -14.6 & 22.7 & 20.75 & $\mathrm{~L} M / 1$ \\
\hline & 249833 & SB1-27 & CAB04-393 & v04105 & Wa-0 & Copecion & davisi & -14.9 & 20.9 & 20.75 & $\mathrm{R} \mathrm{M} / 1$ \\
\hline & 249856 & SB1-29 & CAB04-408 & v04105 & Wa-0 & Ectocion & parvus & -13.1 & 21.7 & 20.75 & $\mathrm{RP} / 3$ \\
\hline & 249858 & SB1-30 & CAB04-410 & v04105 & Wa-0 & Ectocion & parvus & -16.6 & 22.2 & 20.75 & $\mathrm{~L} \mathrm{M} / 1$ \\
\hline & 249859 & SB1-31 & CAB04-411 & v04105 & Wa-0 & Copecion & davisi & -14.5 & 23.1 & 20.75 & $\mathrm{R} \mathrm{M} / 1$ \\
\hline & 249861 & SB1-32 & CAB04-413 & v04105 & Wa-0 & Copecion & davisi & -14.8 & 22.0 & 20.75 & L M2/ \\
\hline & 251619 & SB1-33 & CAB06-123 & v04105 & Wa-0 & Copecion & davisi & -14.2 & 22.7 & 20.75 & $\mathrm{LP} / 4$ \\
\hline & 251620 & SB1-34 & CAB06-124 & v04105 & Wa-0 & Ectocion & parvus & -14.3 & 24.3 & 20.75 & $\mathrm{R} \mathrm{M} / 2$ \\
\hline & 252519 & SB1-35 & CAB07-572 & v04105 & Wa-0 & Copecion & davisi & -14.2 & 22.9 & 20.75 & $\mathrm{R} \mathrm{M} / 2$ \\
\hline & 250876 & SB1-38 & CAB05-322 & v05052 & Wa-0 & Ectocion & parvus & -14.6 & 21.4 & 22.57 & $\mathrm{R} \mathrm{M} 2 /$ \\
\hline & 251137 & SB1-39 & CAB05-450 & v05127 & Wa-0 & Sifrhippus & sandrae & -14.6 & 25.1 & 15.24 & $\mathrm{M} / 3$ \\
\hline & 252100 & SB1-40 & CAB06-486 & v06126 & Wa-0 & Copecion & brachypternus & -15.2 & 22.8 & 45.91 & $\mathrm{~L} \mathrm{M} / 2$ \\
\hline & 250113 & SB1-42 & CAB04-534-1 & v04162 & Wa-0? & Coryphodon & eocaenus & -15.5 & 21.8 & 19.91 & enamel frag. \\
\hline & 249351 & SB1-43 & CAB04-136 & v04034 & Wa-0 & Coryphodon & eocaenus & -15.4 & 22.6 & 19.80 & enamel frag. \\
\hline
\end{tabular}




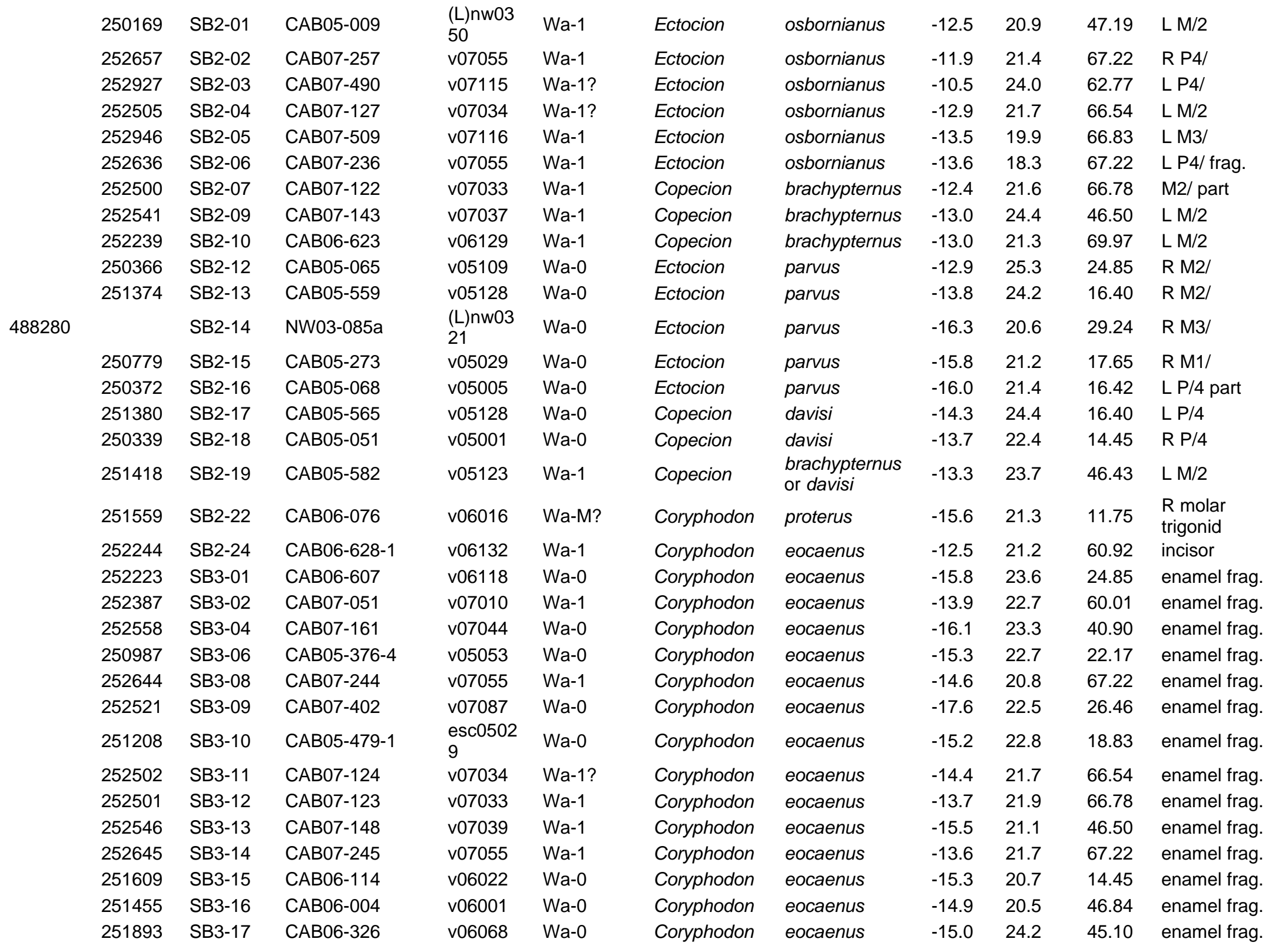




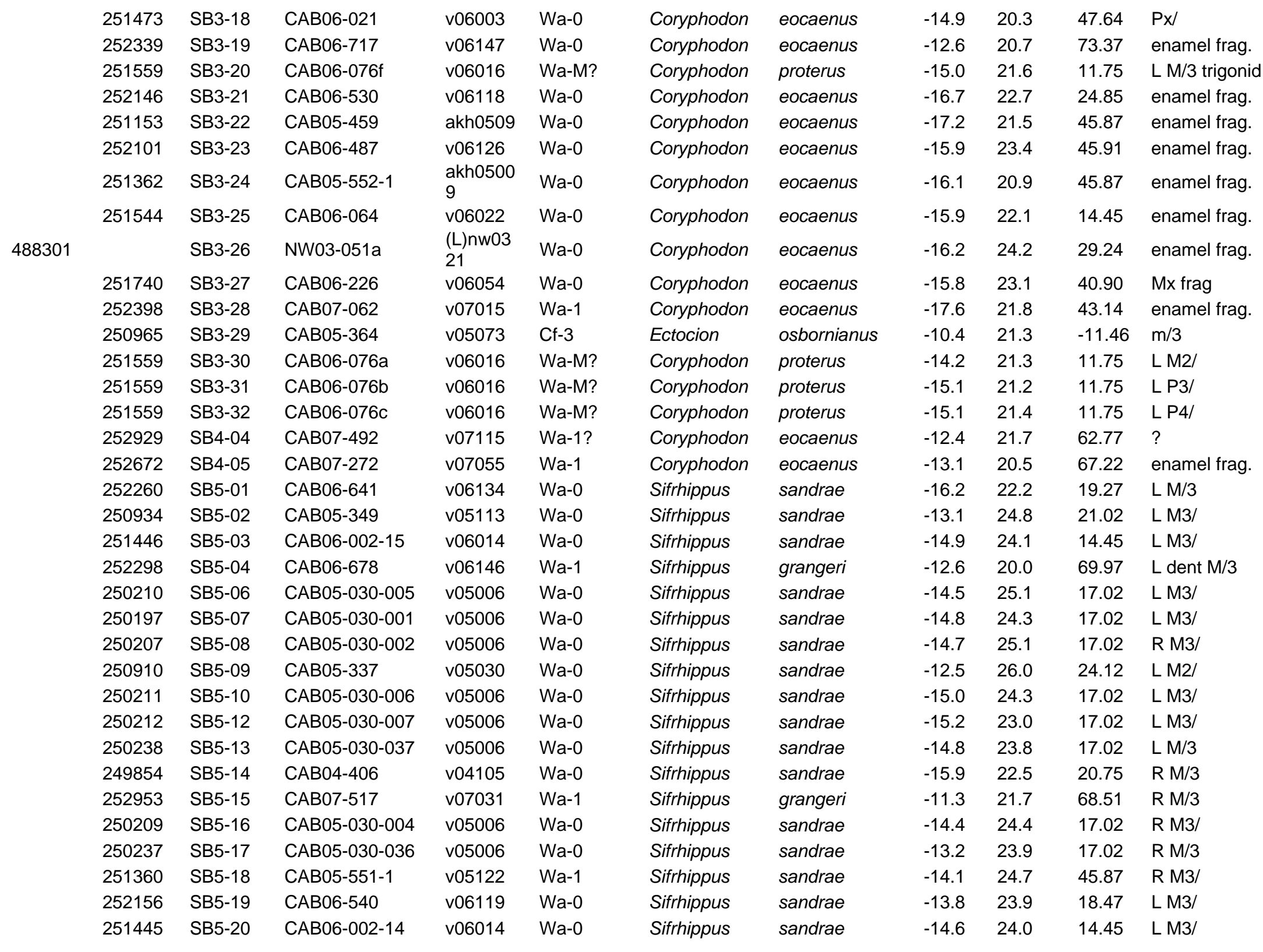




\begin{tabular}{|c|c|c|c|c|c|c|c|c|c|c|c|}
\hline & 251928 & SB5-21 & CAB06-344 & v06084 & Wa-0 & Sifrhippus & sandrae & -17.0 & 21.4 & 40.90 & L M3/ \\
\hline & 252697 & SB5-22 & CAB07-287 & v07056 & Wa-1 & Sifrhippus & grangeri & -11.9 & 20.2 & 68.57 & L M3/ \\
\hline & 252234 & SB5-23 & CAB06-618 & v06129 & Wa-1 & Sifrhippus & grangeri & -12.9 & 20.8 & 69.97 & $\mathrm{R} \mathrm{M} / 3$ \\
\hline & 252040 & SB5-24 & CAB06-435 & v06105 & Wa-1 & Sifrhippus & grangeri & -16.1 & 22.3 & 46.45 & L M3/ \\
\hline & 251658 & SB5-25 & CAB06-157 & v06039 & Wa-0 & Sifrhippus & sandrae & -14.8 & 25.0 & 40.90 & L M/3 \\
\hline & 251175 & SB5-26 & CAB05-466 & v05118 & Wa-0 & Sifrhippus & sandrae & -14.9 & 22.8 & 25.19 & $M / 3$ \\
\hline & 252007 & SB5-27 & CAB06-402 & v06109 & Wa-0? & Sifrhippus & sandrae & -14.9 & 22.8 & 40.90 & R M3/ \\
\hline \multirow[t]{9}{*}{488295} & & SB5-28 & NW03-038 & $\begin{array}{l}\text { (L)nw03 } \\
18\end{array}$ & Wa-0 & Sifrhippus & sandrae & -13.7 & 24.7 & 31.40 & $M / 2$ \\
\hline & 252242 & SB5-29 & CAB06-626 & v06130 & Wa-1 & Sifrhippus & grangeri & -11.7 & 20.5 & 71.42 & L M/3 \\
\hline & 252431 & SB5-30 & CAB07-037 & v07008 & Wa-1 & Sifrhippus & grangeri & -11.5 & 19.6 & 48.10 & R M3/ \\
\hline & 252730 & SB5-31 & CAB07-320 & v07061 & Wa-1 & Sifrhippus & grangeri & -12.0 & 17.6 & 65.67 & $\mathrm{R} \mathrm{M} / 3$ \\
\hline & 251440 & SB5-32 & CAB06-002-09 & v06014 & Wa-0 & Sifrhippus & sandrae & -15.2 & 25.0 & 14.45 & L M/3 \\
\hline & 252639 & SB5-33 & CAB07-239 & v07055 & Wa-1 & Sifrhippus & grangeri & -11.1 & 20.7 & 67.22 & L M/3 \\
\hline & 251713 & SB5-34 & CAB06-207 & v06046 & Wa- 0 & Sifrhippus & sandrae & -15.8 & 22.7 & 14.45 & L M3/ \\
\hline & 252357 & SB5-36 & CAB06-735 & v06134 & Wa-0 & Sifrhippus & sandrae & -15.4 & 23.0 & 19.27 & L M3/ \\
\hline & 250208 & SB5-37 & CAB05-030-003 & v05006 & Wa-0 & Sifrhippus & sandrae & -14.9 & 21.8 & 17.02 & R M3/ \\
\hline \multirow[t]{19}{*}{493918} & & SB5-38 & NW03-046 & $\begin{array}{l}\text { (L)nw03 } \\
21\end{array}$ & Wa-0 & Sifrhippus & sandrae & -14.3 & 21.4 & 29.24 & $\mathrm{R} \mathrm{M} / 3$ \\
\hline & 251432 & SB5-39 & CAB06-002-01 & v06014 & Wa-0 & Sifrhippus & sandrae & -14.9 & 24.7 & 14.45 & $\mathrm{R} \mathrm{M} / 3$ \\
\hline & 250963 & SB8-01 & CAB05-362 & V05076 & cf-3 & Coryphodon & proterus & -13.2 & 20.5 & 1.46 & $\mathrm{R}$ C1/ \\
\hline & 250890 & SB8-26 & CAB05-328 & v05056 & Cf-3 & Ectocion & osbornianus & -9.8 & 22.5 & 5.38 & L M/3 \\
\hline & 250891 & SB8-28 & CAB05-329 & v05056 & Cf-3 & Ectocion & osbornianus & -7.0 & 25.3 & 5.38 & LM3/ \\
\hline & 253630 & SB8-30 & CAB08-639 & v04004 & Cf-3 & Ectocion & osbornianus & -9.7 & 23.5 & 2.82 & L P4/ \\
\hline & 250080 & SB8-39 & CAB04-549 & v04005 & Cf-3 & Ectocion & osbornianus & -10.4 & 20.1 & 2.29 & M3/ \\
\hline & 253628 & SB8-44 & CAB08-637 & v04004 & Cf-3 & Ectocion & osbornianus & -9.7 & 17.5 & 2.82 & $\mathrm{RM} / 1$ \\
\hline & 250808 & SB8-45 & CAB05-285 & v05031 & Cf-3 & Ectocion & osbornianus & -10.0 & 24.5 & 3.98 & LM1/ \\
\hline & 250825 & SB8-48 & CAB05-297 & v05063 & Cf-3 & Ectocion & osbornianus & -9.8 & 26.0 & 5.99 & LP/3 \\
\hline & 252451 & SB8-49 & CAB07-072 & v07018 & Cf-3 & Ectocion & osbornianus & -7.1 & 27.7 & 4.98 & M3/ \\
\hline & 249299 & SB8-50 & CAB04-095 & v04017 & Cf-3 & Ectocion & osbornianus & -10.7 & 22.9 & 2.14 & LP/3 \\
\hline & 249298 & SB8-51 & CAB04-094 & v04017 & Cf-3 & Ectocion & osbornianus & -7.8 & 23.3 & 2.14 & RP3/ \\
\hline & 253641 & SB9-01 & CAB08-650 & v08140 & Wa-0 & Sifrhippus & sandrae & -14.8 & 24.8 & 43.35 & $\mathrm{RM} 3 /$ \\
\hline & 253382 & SB9-02 & CAB08-390 & v08091 & Wa-0 & Sifrhippus & sandrae & -14.1 & 23.4 & 36.48 & LM3/ \\
\hline & 253319 & SB9-04 & CAB08-327 & v08077 & Wa-0 & Sifrhippus & sandrae & -12.6 & 26.4 & 40.90 & LM/3 \\
\hline & 254047 & SB9-05 & CAB08-967 & v08185 & Wa-0 & Sifrhippus & sandrae & -15.8 & 21.4 & 20.72 & RM3/ \\
\hline & 253406 & SB9-06 & CAB08-414 & v08077 & Wa-0 & Sifrhippus & sandrae & -12.2 & 26.7 & 40.90 & RM1/ broken \\
\hline & 253058 & SB9-07 & CAB08-065 & v08016 & Wa-0 & Sifrhippus & sandrae & -15.1 & 23.0 & 31.66 & LP4/ \\
\hline
\end{tabular}




\begin{tabular}{|c|c|c|c|c|c|c|c|c|c|c|}
\hline 252554 & SB9-08 & CAB07-157 & v07044 & Wa-0 & Sifrhippus & sandrae & -13.2 & 22.3 & 40.90 & $\mathrm{LP} / 3$ \\
\hline 253727 & SB9-09 & CAB08-739 & v08161 & Wa-0 & Sifrhippus & sandrae & -13.2 & 24.4 & 45.10 & LM2/ \\
\hline 252748 & SB9-10 & CAB07-333 & v07066 & Wa-0? & Sifrhippus & sandrae & -12.5 & 30.5 & 40.90 & LP4/ \\
\hline 253987 & SB9-12 & CAB08-1053 & v08191 & Wa-0 & Sifrhippus & sandrae & -14.6 & 24.6 & 40.90 & RP3/ \\
\hline 253475 & SB9-13 & CAB08-483 & v08112 & Wa-0 & Sifrhippus & sandrae & -12.0 & 27.1 & 45.10 & LM2/ \\
\hline 253371 & SB9-14 & CAB08-379 & v08087b & Wa-0 & Sifrhippus & sandrae & -15.2 & 22.8 & 45.10 & RP4/ \\
\hline 253509 & SB9-15 & CAB08-517 & v08106 & Wa-0 & Sifrhippus & sandrae & -16.8 & 22.0 & 24.35 & $\mathrm{M} / 2$ \\
\hline 252772 & SB9-16 & CAB07-355 & v07008 & Wa-1 & Sifrhippus & grangeri & -12.3 & 23.8 & 48.10 & \multirow{3}{*}{$\begin{array}{l}\text { RM1/ } \\
\text { LM/1 or M/2 } \\
\text { frag. }\end{array}$} \\
\hline 252545 & SB9-17 & CAB07-147 & v07039 & Wa-1 & Sifrhippus & grangeri & -12.6 & 25.8 & 46.50 & \\
\hline 253272 & SB9-18 & CAB08-280 & v08070 & Wa-1 & Sifrhippus & sandrae & -13.3 & 25.2 & 40.90 & \\
\hline 253988 & SB9-19 & CAB08-1054 & v08191 & Wa-0 & Sifrhippus & sandrae & -14.4 & 25.0 & 40.90 & RM2/ \\
\hline 253558 & SB9-21 & CAB08-566 & v08114 & Wa-1 & Sifrhippus & grangeri & -10.2 & 21.2 & 62.77 & LM3/ \\
\hline 253768 & SB9-22 & CAB08-779 & v08173 & Wa-0 & Sifrhippus & sandrae & -15.5 & 25.0 & 40.90 & $\mathrm{RM} 1 /$ \\
\hline 253064 & SB9-23 & CAB08-071 & v08011 & Wa-0 & Sifrhippus & sandrae & -13.2 & 25.6 & 32.07 & $\mathrm{~L} \mathrm{M} / 2$ \\
\hline 253556 & SB9-24 & CAB08-564 & v08114 & Wa-1 & Sifrhippus & grangeri & -12.2 & 20.1 & 62.77 & $\mathrm{RM} / 3$ broken \\
\hline 253561 & SB9-25 & CAB08-569 & v08114 & Wa-1 & Sifrhippus & grangeri & -11.5 & 23.8 & 62.77 & $\mathrm{RM} 3 /$ \\
\hline 254092 & SB9-26 & CAB08-1108 & v08192 & Wa-1 & Sifrhippus & grangeri & -12.4 & 28.0 & 46.50 & LM/2 \\
\hline 253250 & SB9-27 & CAB08-258 & v08059 & Wa-0 & Sifrhippus & sandrae & -15.4 & 21.6 & 23.85 & RM3/ \\
\hline 254089 & SB9-28 & CAB08-1105 & v08192 & Wa-1 & Sifrhippus & grangeri & -12.6 & 22.7 & 46.50 & $\mathrm{M} / 3$ \\
\hline 253063 & SB9-29 & CAB08-070 & v08011 & Wa-0 & Sifrhippus & sandrae & -13.8 & 26.7 & 32.07 & $\mathrm{M} / 2$ \\
\hline
\end{tabular}

Pre-CIE (Cf-3) occurrences of taxa otherwise known only from the PETM, presumed to be contaminants based on excursion-level $\delta^{13} \mathrm{C}$ values

\begin{tabular}{|c|c|c|c|c|c|c|c|c|c|}
\hline SB1-41 & CAB07-104 & v07027 & Cf-3 & Ectocion & parvus & -15.2 & 22.6 & -3.25 & $\mathrm{R} \mathrm{M} / 1$ or $\mathrm{M} / 2$ \\
\hline SB1-37 & CAB04-544 & v04167 & Cf-3 & Copecion & davisi & -14.3 & 22.6 & & $\mathrm{~L} M / 1$ or $\mathrm{M} / 2$ \\
\hline SB1-12 & CAB04-130 & v04031 & Cf-3 & Ectocion & parvus & -13.9 & 23.7 & & L M1/ \\
\hline SB8-27 & CAB08-645 & v08151 & Cf-3 & Copecion & sp. & -13.0 & 24.4 & 5.68 & $\mathrm{R} \mathrm{M} / 1$ or $\mathrm{M} / 2$ \\
\hline SB4-28 & CAB04-076 & v04014 & Cf-3 & Copecion & davisi & -12.4 & 26.3 & 2.12 & $\mathrm{R} \mathrm{M} / 2$ \\
\hline
\end{tabular}

